\title{
Diskuse
}

\section{Dějiny obětí}

\section{K historiografii a politice identity českých židư*}

\section{Vít Strobach}

Hypotéza, jíž se budu věnovat v první části textu (kapitola „Politika vědy“), zní ve zkratce takto: V posledních zhruba dvaceti letech jsme v české historiografii svědky poměrně širokého uplatnění dějin obětí, či - slovy Salo W. Barona - plačtivého pojetí židovských dějin. ${ }^{1} \mathrm{Na}$ tento fenomén narážíme i v jiných zemích a v různých obdobích poválečného vývoje. Dějiny židơ ${ }^{2}$ a antisemitismu se dostaly do úzkého kontaktu. Na specifika a souvislosti psaní o židech, respektive antisemitismu $\mathrm{v}$ daném interpretačním rámci se zaměřím v první půli textu. Ve všech třech níže definovaných, typizovaných výpovědích české historiografie („národ“, „totalita“, „kultura“) má právě narativ oběti zásadní roli.

* Tato studie vznikla v roce 2012 pro časopis Soudobé dějiny, kde po jistých peripetiích a jen s drobnými úpravami vychází. Je na čtenárích a na dalších badatelích, aby nejen zhodnotili oprávněnost tezí, které studie předkládá, ale i změny, ke kterým v posledních pěti letech $\mathrm{v}$ rámci zkoumaného jevu došlo. $\mathrm{V}$ další diskusi a analýzách by bylo rovněž zapotřebí vzít $\mathrm{v}$ potaz drobnější rozlišení vývoje během posledních více než dvaceti let.

1 K Baronovu pojetí židovských dějin srv. BRENNER, Michael: Prophets of the Past: Interpreters of Jewish History. Princeton, Princeton University Press 2010, s. 221-231.

2 Při psaní slova žid/židé volím malé počáteční písmeno, pokud souvislosti (odkaz na národní identitu) nevyžadují jinak. 
Dopředu musím upozornit na několik omezení. Text si neklade za cíl analyzovat českou historiografii zabývající se židy či antisemitismem jako takovou. Věnuje se pouze historiografii z období 1989 až 2012, která se podílela na reprodukci dějin obětí, specifikům tohoto výkladu, jeho detailnějšímu vymezení, historickým figurám, s nimiž autoři a autorky pracují, a možným reziduím jejich interpretací. Nechávám $\mathrm{k}$ dalšímu posouzení, jak silné zastoupení měl a má narativ oběti v celkovém penzu dané odborné literatury. Vycházím z prací týkajících se moderních dějin (19. a 20. století), o nichž si vzhledem k dlouhodobému zájmu dovolím hovořit, přičemž historiografie holokaustu - nikoliv ovšem některé předpoklady jeho chápání - bude hrát okrajovou úlohu. Př́ležitostně se dotknu zahraniční literatury, to ale jen potud, nakolik ovlivnila zdejší odbornou a veřejnou diskusi.

Status obětí je důležitou součástí artikulací bojů o uznání nacionalistických hnutí a obecněji důležitým definičním znakem kolektivních identit. ${ }^{3}$ Namísto relativně diskutovaného tématu nacionalizace „majoritních společnosti““ jednotlivých národních států jsou předmětem druhé části mé studie dějiny obětí v kontextu politiky „minoritni“ identity (kapitola „Politika identity“). Opět je zapotřebí zmínit některé metodologické a heuristické limity. Na omezeném prostoru se nelze zabývat celým heterogenním polem politik židovské identity, jež se střetávají v institucích názorově různorodé komunity. ${ }^{4}$ Pokusím se pojmenovat charakteristické rysy pouze jedné, avšak vlivné politiky identity, a to právě té, která přisoudila oběti ústřední místo ve svém výkladu židovských dějin. Analýza se přitom zaměří v prvé řadě na podobu historické, kolektivní paměti. Prameny je proto nutné poněkud rozšíriti. Využiji tedy i texty z reprezentativního časopisu českých židovských obcí Roš chodeš.

Mou hlavní snahou není poskytnout vyčerpávající analýzu, ale obě perspektivy spojit a obrátit pozornost ke dvěma souvisejícím problémům: $\mathrm{k}$ analýze historiografie moderních židovských dějin, ${ }^{5}$ získávající v mezinárodní historické obci

3 Srv. HALlAMA, Peter: Geschichtswissenschaften, Memory Studies und der Passive Turn: Zur Frage der Opferperspektive in der erinnerungskulturellen Forschung. In: FRANZEN, Erik K. - SCHULZE WESSEL, Martin (ed.): Opfernarrative: Konkurenzen und Deutungskämpfe in Deutschland und im östlichen Europa nach dem Zweiten Weltkrieg. München, Oldenbourg 2012, s. 9-27. K „paměti oběti“"ve vztahu k holokaustu a komunismu srv. BLAIVE, Muriel: The Memory of the Holocaust and of Communist Repression in a Comparative Perspective: the Cases of Hungary, Poland and Czechoslovakia/the Czech Republic. In: BLAIVE, Muriel - GERBEL, Christian - LINDENBERGER, Thomas (ed.): Clashes in European Memory: The Case of Communist Repression and the Holocaust. Innsbruck - Wien - Bozens, Studien 2011, s. 154-173, zde s. 162-165.

4 Samotný pojem „komunita“ je ostatně možné použít právě jen s vědomím ideové a sociální různorodosti lidí spojených poměrně bohatou institucionální strukturou veřejného života českých židi̊.

5 Analýzy historiografických textů získaly v poválečné evropské, izraelské a americké akademické obci důležitou roli, především v souvislosti s reflexí psaní o holokaustu (srv. např. YOUNG, James Y.: Writing and Rewriting the Holocaust: Narrative and the Consequences of Interpretation. Bloomington, Indiana University Press 1988; DREYFUSS, Jean-Marc LANGTON, Daniel (ed.): Writing the Holocaust (Writing History). London, Bloomsbury 2011). Objevují se také obecnější analýzy psaní o židovských dějinách (srv. např. BRENNER, M.: Prophets of the Past). 
důležité místo, a konkrétně k narativní figuře oběti, jež - ovšem málo reflektována -zobecněla v části české historiografie a politice identity českých židů. Identifikuji určitá schémata výpovědí vznikající na styčných místech komplementárních diskurzů vědy a paměti a obsahující normativní hodnocení židovské historie. Kolektivní pamět i historická věda jsou specifickými, byt nikoliv zcela stejnorodými podobami historického vědění a součástí společenské identity. Tuto koexistenci je zapotřebí nejen konstatovat, ale také reflektovat a pokusit se udržet kritický rozměr vědy. Proto poukazuji na souvislosti v průběhu jednotlivých kapitol a volím poněkud nestandardní strukturu textu. Propojení obou hlavních problémů a zároveň prvních dvou kapitol je také obsahem třetí kapitoly, poukazující na konkrétní místo, kde k tomuto setkání dochází, a na důsledky, jež si zasluhují pozornost kritického myšlení (kapitola „Mezi politikou vědy a identity“).

Zvláště u některých témat představím pouze obecnější propozice vybízející k další diskusi a analýzám, které by poukázaly na proměnu zkoumaných jevů v polistopadovém období a zohlednily by další témata (starší dějiny židů a antisemitismu, fenomén holokaustu aj.).

\section{Politika vědy}

Michal Frankl, zabývající se psaním o dějinách holokaustu mezi lety 1948 a 1989, popisuje narativní schéma komunistické historiografie, do něhož musely v daném období zapadat dějiny antisemitismu a židů obecně. Podle autora to znamenalo faktickou asimilaci těchto dějin $v$ dějinách tř́dního boje a mimo jiné dovolovalo zastírat specifické utrpení židů během nacistické okupace. Frankl se domnívá, že polistopadová historiografie tento narativ korigovala, ale dosud definitivně nesituovala (Verortung) holokaust, respektive útlak židů, do dějin pronásledování a odboje českého národa. ${ }^{6}$ Boaz Cohen daný jev zaznamenává v celém „východním bloku“. Doslova píše, že židovské oběti holokaustu v historiografiích těchto zemí ztratily v poválečném období svou identitu a zvláštní osud. Asimilační tendence, i když nikoliv tak výrazné, byly podle Cohena patrné také v historiografiích zemí západní Evropy, přičemž tento stav se pomalu dařilo napravovat až od sedmdesátých let v Izraeli a od devadesátých let v dalších zemích. Navrácení hlasu mlčícím obětem

6 Srv. FRANKL, Michal: Die „Endlösung der Judenfrage“ und die Narrative der Tschechischen Geschichte 1945-1989. In: BRENNER, Christiane - FRANZEN, Erik Karl - HASLINGER, Peter - LUFT, Robert (ed.): Geschichtsschreibung zu den böhmischen Ländern im 20. Jahrhundert: Wissenschaftstraditionen - Institutionen - Diskurse. München, Oldenbourg 2006, s. 255-277. Jev, o kterém tu ještě bude řeč a který zmiňuje Frankl spíše na okraj - tj. etnocentrické pojetí českých národních dějin - rozvedli jako hlavní problém nedostatečného výzkumu holokaustu v předlistopadovém a částečně i polistopadovém období Michal Kopeček a Pavel Kolář (KOLÁŘ, Pavel - KOPEČEK, Michal: A Difficult Quest for New Paradigms: Czech Historiography After 1989. In: ANTOHI, Sorin - TRENCSÉNYI, Balázs - APOR, Péter (ed.): Narratives Unbound: Historical Studies in Post-Communist Eastern Europe. BudapestNew York, Central European University Press 2007, s. 173-248, zde s. 208 n. a 226). 
je v jeho pojetí zcela svázáno s představou překonání asimilace židovské identity, respektive paměti, jejímuž sebevyjádření se historikové do té doby stavěli na odpor. ${ }^{7}$

O situování holokaustu, ale také antisemitismu a samotných židovských dějin psali a píši i další historikové; všechna tři témata jsou v těchto textech velmi úzce spjatá. Objevují se v nich typické figury jako „bílé místo“ či „splácení dluhu“. ${ }^{8}$ Tato metaforická vyjádření signalizují přirozený (morální) nárok vyplývající z dřívějšího zneuznání specifičnosti židovských dějin (a/tedy identity) v období diktatury komunistické strany. Splacení dluhu, situování a zaplňování „bílých míst“ v daných souvislostech naznačují obrat od údajně nenormální situace k přirozenému stavu. V praxi se snaha po „normalitě“ ukazuje především jako odlišení židovských dějin a odmítnutí zmíněné asimilační a antisemitské tendence komunistické historiografie. Do centra pozornosti byla postavena židovská identita.

Tento jev souvisí mimo jiné se změnou obecného paradigmatu sociálních věd v Československu, respektive České republice, a celém bývalém „východním bloku“. Strukturující mřížka sociálního (trrídního) konfliktu byla v sociální teorii po roce 1989 do značné míry nahrazena hlediskem (kulturních, národních, etnických) identit. Souvisí s tím i obecnější proměna artikulace kolektivních zájmů. Univerzální sociální práva vystřídal v jazyce boje o uznání akcent na vyjádření kulturních svébytností a specifických historických pamětí. Svým způsobem byl dohnán vývoj „postmoderní plurality identit“ Západu. Narativní prvek oběti přitom získal důležitou funkci v politikách identit, kde pomáhá legitimizovat partikulární kolektivní - (národní) zájmy. V návaznosti na daný proces získala obět důležitou roli také v historickém výzkumu.

Autonomie bádání o židovských dějinách a jeho úzké provázání s výzkumem antisemitismu se ovšem zdají být přirozenou reakcí na historiografii ovlivněnou marxisticko-leninským paradigmatem jen po velmi zběžném pozorování.

\section{Instituce}

V devadesátých letech dvacátého století se postupně zrodila historiografie, ale také - alespoň v zárodcích - sociologie, antropologie a kulturologie českých židů.

7 Viz COHEN, Boaz: Jews, Jewish Studies and Holocaust Historiography. In: DREYFUSS, J. M. LANGTON, D (ed.): Writing the Holocaust, s. 100-115, zde s. $100 \mathrm{nn}$.

8 O dějinách židů jako „bílém místu“ české nacionalistické a antisemitskou komunistickou oficialitou ovlivněné historiografie viz KŘEN, Jan: Bílá místa v našich dějinách? Praha, Lidové noviny 1990, s. 82. Petr Němec píše o „dluhu“ československé historiografie k dějinám židů, kteří (jak vyplývá z úvodu jeho příspěvku) mají být zkoumáni coby „vždy odlišná skupina“ (NĚMEC, Petr: Nové práce k historii československých Židů ve 20. století. In: Český časopis historický, roč. 90, č. 4 (1992), s. 588-593). Němec, stejně jako třeba Helena Krejčová, odmítá, že by hlavním problémem byla absence výzkumu nacistické perzekuce židů, a stanovují jiné, „aktuálnější “ problémy. Podíváme-li se blíže na témata navrhovaná Helenou Krejčovou, vidíme ovšem absolutní dominanci těch, jež organizují dějiny židů jako zcela specifického fenoménu (KREJČOVÁ, Helena: Osudy židovské komunity v letech 1938-1948: Stav výzkumu. In: KOCIAN, Jiří - TƯMA, Oldřich (ed.): Deset let soudobých dèjin: Jednání sekce Soudobé dějiny na VIII. sjezdu českých historiků. Praha, Ústav pro soudobé dějiny AV ČR 2001, s. 65-71). 
O popularizační a vědeckou produkci z oblasti dějin židů a antisemitismu se začaly starat kulturní instituce, nakladatelství, vědecké či vzdělávací ústavy. Do výzkumných i pedagogických projektů proudí poměrně nemalé prostředky tuzemských i zahraničních grantových agentur a nadací. Na následujících řádcích výčtem zmíním české instituce, které považuji za klíčové z pohledu historiografie moderních židovských dějin. ${ }^{9}$ Každá z nich by zasloužila vlastní analýzu, k níž na daném prostoru není možné přistoupit.

Na vysokých školách zatím nedošlo k interdisciplinárnímu soustředění a oddělení tématu od obecnějších oblastí výuky a výzkumu, dějí se v tomto směru nicméně první pokusy (Pražské centrum židovských studií na Filozofické fakultě Univerzity Karlovy). ${ }^{10} \mathrm{~V}$ posledních letech se projevoval o téma moderních židovských dějin v prostředí vysokých škol poměrně intenzivní zájem; krom přednášek a kurzovních předmětů jsou organizovány konference, zvyšuje se i počet vydávaných publikací. Větší aktivitu v tomto směru vykazuje například Fakulta humanitních studií v Praze (Společenskovědní modul), Filozofická fakulta Západočeské univerzity v Plzni (Katedra blízkovýchodních studii) a Filozofická fakulta Univerzity Palackého v Olomouci (Centrum judaistických studií Kurta a Urschuly Schubertových). Přihlédneme-li $\mathrm{k}$ výuce, $\mathrm{k}$ odborným publikacím i další veřejné činnosti spojené $\mathrm{s}$ těmito ústavy, je patrné, že výraznou roli hrají mimo jiné témata spjatá s antisemitismem, včetně jeho soudobých forem. ${ }^{11}$

Jediným akademickým pracovištěm zabývajícím se ryze historickým výzkumem židovských dějin bylo Oddělení pro židovská, národnostní a menšinová studia v Ústavu pro soudobé dějiny AV ČR, v. v. i., které v současnosti nahradila Pracovní skupina pro inkluzivní dějiny. ${ }^{12}$ Přes svi̊j název a plány zakladatelů ústavu ${ }^{13}$ se pracoviště v minulých letech profilovalo téměř výhradně problematikou antisemitismu a holokaustu českých židů. Jedním z nejvýraznějších projektů ústavu byla

9 Ze zahraničních institucí jmenujme alespoň Středoevropskou univerzitu (Central European University) v Budapešti a její židovská studia, kde působili a působí autoři zabývající se komparativní perspektivou sociálních dějin židů a antisemitismu (nejen) středoevropského prostoru; srovnání tohoto a dalších (např.) amerických a izraelských pracovišt zde ovšem musím vzhledem $\mathrm{k}$ prostoru pominout.

10 V Ústavu českých dějin FF UK došlo k (prozatím neúspěšnému) pokusu vybudovat samostatný studijní program „Moderní dějiny Židů ve střední Evropě“.

11 Asi nejvýrazněji se dnes v daném ohledu profiluje Katedra blízkovýchodních studií na Západočeské univerzitě se svou velmi ambiciózně pojatou řadou monografií a sborníků o antisemitismu (srv. TYDLITÁTOVÁ, Věra - HANZOVÁ, Alena (ed.): Reflection on Anti-Semitism: Anti-Semitism in historical and anthropological perspectives. Plzeň, Západočeská univerzita 2008; TYTÉŽ (ed.): Anatomy of Hatred: Essays on Anti-Semitism. Plzeň, Západočeská univerzita 2009; BUDIL, Ivo - ARAVA-NOVOTNÁ, Lena - TYDLITÁTOVÁ, Věra - TARANT, Zbyněk (ed.): Nová doba, stará zloba: Soudobý antisemitismus v historickém kontextu. Plzeň, Západočeská univerzita 2010).

12 Aktivity této pracovní skupiny týkající se židovských dějin jsou přístupné na adrese $w w w$. jewishhistory.usd.cas.cz [cit. 2016-06-20].

13 Srv. KREJČOVÁ, Helena: Oddělení pro židovská studia a Centrum pro dokumentaci majetkových převodů kulturních statků obětí 2 . světové války. In: Terezínské listy, roč. 33. Terezín - Praha, Památník Terezín - Nakladatelství Oswald 2005, s. 19-27. 
dokumentace osudů uměleckých děl patřících původně obětem nacistické perzekuce. ${ }^{14}$ Danému výzkumu se věnuje také Ústav pro studium totalitních režimů; vzhledem $\mathrm{k}$ programové agendě tohoto pracoviště jde především o výzkum spisů represivních orgánů, př́ípadně dalších institucí „totalitních režimů“. Židovské dějiny jsou v koncepci ústavu považovány za součást dějin útlaku (režimu) a odboje (společnosti) z let 1938 až $1989 .{ }^{15}$

Už po letmém pohledu na penzum polistopadových prací ke sledovaným tématům nemůžeme přehlédnout důležitou roli tří specifických vzdělávacích a výzkumných institucí: Židovského muzea v Praze, Památníku Terezín a Institutu Terezínské iniciativy. Židovské muzeum v Praze, pokud jde o historiografii moderních dějin, se věnuje z velké části dějinám holokaustu, respektive antisemitismu. ${ }^{16}$ Památník Terezín se soustředí ve své badatelské činnosti především na represivní orgány nacistické moci - ze značné části (nikoliv ale pouze) na takzvané konečné řešení židovské otázky. Jím se téměř výlučně zabývá také Institut Terezínské iniciativy. ${ }^{17}$ Všechny tři instituce a místa, k nimž odkazují, jsou důležitými monumenty kolektivní paměti českých židů. Mají vliv, byt jistě ne tak zásadní, i na to, jak jsou židovské dějiny a antisemitismus vnímány širší veřejností, a na obecnější rovině také na to, jak si tato společnost představuje své vlastní dějiny. ${ }^{18}$ Vědní politika a politika paměti těchto institucí mají nesporný vliv na podobu polistopadové historiografie českých židů. Ovlivňují, byt' (vzhledem k existenci dalších institucí) jistě zcela nedeterminují, dějepisnou produkci, interpretační rámce i výběr témat, o nichž bude dále řeč. ${ }^{19}$

14 Pracoviště vytvářelo podklady pro restituci židovského majetku. Za tímto účelem vzniklo Centrum pro dokumentaci majetkových převodů kulturních statků obětí 2. světové války. Centrum od roku 2012 působí jako samostatná obecně prospěšná společnost (o.p.s.) mimo struktury AV ČR. Další informace jsou k dispozici na webu centra www.cdmp.cz [cit. 2016-09-20].

15 Ke kritické reflexi historiografie a politiky paměti, již spoluutváŕí ÚSTR, srv. KOPEČEK, Michal: Hledání „paměti národa“: Politika dějin, nostalgie a české dějepisectví komunismu. In: Dějiny, teorie, kritika, roč. 4, č. 1 (2007), s. 7-26.

16 K pracovní náplni dvou výzkumných oddělení Židovského muzea v Praze srv. online http:// www.jewishmuseum.cz/cz/czveda_vyzkum.php [cit. 2016-09-20].

17 Přehled o agendě Památníku Terezín si lze udělat z Terezínských listů (přehled obsahů jednotlivých čísel je online dostupný z: http://www.pamatnik-terezin.cz/cz/historie-sbirky-a-vyzkum/terezinske-listy/obsahy-jednotlivych-cisel [cit. 2016-09-20]) a o agendě Institutu Terezínské iniciativy z její ročenky Terezínské studie a dokumenty (přehled obsahů jednotlivých svazků je online dostupný z: http://www.terezinstudies.cz/publications/terezin-studies-documents/terezin-studies-documents.html [cit. 2016-09-20]).

18 Mimo knižní produkce se Židovské muzeum v Praze a Památník Terezín zabývají veřejnou (osvětovou) činností - pořádají výstavy a kulturní akce, připravují propedeutické příručky atd.

19 Vzhledem k produkci zmíněných institucí je zapotřebí alespoň zcela zběžně definovat dvě základní (,ideálni“") tendence psaní o holokaustu. V dalším textu se vrátím k jejich předpokladům, nikoliv ale k samotnému holokaustu. První z nich lze personifikovat jménem historika Miroslava Kárného, spoluzakladatele Terezínské iniciativy. „Škola“spjatá s Kárným, vyrůstající z jeho prací ze 70. a 80. let, do značné míry lpěla na nutnosti studovat holokaust, resp. antisemitismus $\mathrm{v}$ širších souvislostech společenských procesů, sociálněpatologických jevů a diskurzů vyloučení. V dosud základní knize k tématu se Kárný snaží pojmout „konečné řešeni" $v$ širším rámci nacistické a rasové politiky (srv. KÁRNÝ, Miroslav: Tajemství a legendy třetí říše: Sedm sond do historie. Praha, Mladá fronta 1983, zvláště s. 69-91). Podobně 
Nacházíme se tedy v situaci, kdy se židovské dějiny staly poměrně frekventovanými a alespoň z kvantitativního hlediska relativně důležitými tématy české historiografie, se zajištěním poměrně bohatou sítí vědeckých a vzdělávacích pracovište To je oproti období před rokem 1989 důležitá změna. Zároveň převažuje bádání spjaté $s$ antisemitismem, potažmo s různými druhy sociálního, institucionálního, symbolického i fyzického násilí. Problém samožrejmě nepředstavuje (nezbytná) pozornost věnovaná antisemitismu, ale to - abych opět přešel $\mathrm{k}$ hlavní tezi - že jsou dějiny židů velmi často líčeny jako dějiny antisemitismu a naopak. Tento fakt vyplývá z normativních a konceptuálních východisek výzkumu, která překračují hranice jednotlivých pracovišté.

\section{Metoda korespondence}

Pro první pokus uchopit odlišné konceptualizace zvoleného tématu můžeme sáhnout po modelovém přehledu, který vypracoval německý sociolog Klaus Holz. ${ }^{20}$ Spolu s ním lze zařadit český výzkum do mezinárodního kontextu, schematicky popsat východiska zkoumání antisemitismu a také, jak dále uvidíme, dějin židů, přesněji dějin židovských obětí.

Klaus Holz rozdělil poválečné zkoumání antisemitismu do čtyř konceptuálních rovin:

1) S pomocí funkcionalistické teorie jej badatelé popisují na základě utváření identitních vzorců („My“) a konstrukcí společných nepřátel („Oni“) odklánějících vnitřní napětí, respektive agresi z vlastní skupiny směrem ven. Dle Holzova pojetí sem patří například chápání antisemitismu coby reakce ohrožených společenských tř́́d na ekonomickou krizi. ${ }^{21}$

autor ve své polistopadové produkci, jež se nedá oddělovat ostrým řezem od předlistopadové, chápe genocidu židů jako „Vzor“ nacistické politiky uplatňované vůči společenskému celku. Píše tak, že se zrodila „funkčnost genocidy jakožto nástroje vedení války i okupační politiky, která měla být posléze transformována v trvalou kolonizační politiku na dobytých územích“ (TÝŽ: „Konečné rešeni“: Genocida českých židů v německé protektorátní politice. Praha, Academia 1991, s. 14). Obě zmíněné práce zůstaly dodnes v mnohém nepřekonané. Z novějších publikací s podobnými východisky bychom mohli zmínit např́íklad Seemannovu knihu slučující edici dokumentů a soubor statí (SEEMANN, Richard (ed.): Cesta do Wannsee: Konečné řešení takzvané židovské otázky a germanizace českých zemí. Středokluky, Zdeněk Susa 2008). - Druhá tendence se více soustředí na antisemitismus a holokaust jako jevy týkající se židovských dějin. Holokaust coby extrémní projev řetězce protižidovského násilí, majícího původ již ve starověku, je úzce spojován s tisíciletými dějinami židovského národa. Interpretace holokaustu, antisemitismu a dějin židů (Židů) jsou v tomto pojetí na sobě do značné míry navzájem závislé. Druhý pohled na holokaust tedy znamená posun v mnohem obecnějším smyslu (viz výše a níže). Je nutné zmínit fakt, že holokaust - navzdory tomu, o jak frekventované téma se jedná - dosud nebyl zpracován ani formou syntetických prací, ani rozsáhlejších analýz.

20 HOLZ, Klaus: Nationaler Antisemitismus: Wissenssoziologie einer Weltanschauung. Hamburg, Hamburger Edition 2001.

21 Do této kategorie lze zařadit většinu „klasických“ marxistických prací o antisemitismu, Holz sem ale řadí i u nás poslední dobou častěji citovanou historičku Shulamit Volkovovou. Česká historiografie přejímá asi nejčastěji její studii „Antisemitism as a Cultural Code: 
2) Korespondenční teorie hledá příčiny antisemitismu ve vztahu mezi (křestanskou či jinou) většinou a (židovskou) menšinou. Autoři ovlivnění touto koncepcí se jej snaží popsat jako přímou reakci na „židovskou jinakost“, explicitně či implicitně stanovují konflikt „My“ versus „Oni“, tj. židé versus křestané, Arabové a podobně. ${ }^{22}$

3) Vývoj kauzální teorie je podle Holze spojen s pracemi neomarxistických filozofů (Theodor Adorno, Max Horkheimer, Erich Fromm aj.). Neomarxisté k sociologickým východiskům přidávají psychoanalytická. Rozpad otcovské autority byl podle nich doprovázen osvojením si vnější, formální autority a přejímáním předsudečného myšlení a násilí vybíjeného na slabších jedincích, nejlépe zranitelných sociálních skupinách. Agrese vưči židům symbolicky nahradila návrat k moci odcizené výrobci spolu s produktem jeho práce v rámci kapitalistického systému vykořistování.

4) Poslední Holzovou paradigmatickou koncepcí je diferenční teorie, zkoumající obrazy cizího, a především „národního druhého“ v jazyce nacionalismu. Antisemitismus podle této teorie nevychází z přímé zkušenosti s jinakostí, ale odpovídá představám o vlastní skupině. Židé se vymaňují z chápání cizince, „národního druhého“, stávají se cizím - nestejným prvkem porušujícím „světový rád“ národů žijících vedle sebe, a proto vystupují jako objekt represe. ${ }^{23}$

Holzovo schéma umožňuje stanovit základní metodologický problém české historiografie židovských dějin. Jen zcela výjimečně se setkáváme s pracemi ovlivněnými či zařaditelnými pouze do první, či poslední šablony, případně do obou dvou zároveň. ${ }^{24}$ Kauzální teorie v ní nemá prakticky žádný vliv. Jinak se autoři často pohybují mezi všemi ostatními koncepcemi, mezi nimiž má nicméně zásadní postavení „korespondence“. Patrná je nesmělost, s níž badatelé přistupují k sociálním teoriím, $\mathrm{k}$ analýze antisemitismu v rámci širšího sociálního konfliktu, modernizačního procesu, populační politiky, utváření národního státu a podobně. Konečně, přitažlivost mezi přístupem rezignujícím na teorii a korespondenční teorií konstatuje i Klaus Holz.

Výzkum antisemitismu se $\mathrm{v}$ (jakkoliv intuitivní) korespondenční teorii stává de facto výzkumem dějin židů. Na jejich (konfliktním) vztahu s majoritou totiž údajně stojí formálně se proměňující, nicméně permanentní fakt antisemitismu. Stereotyp, xenofobie a rasismus se zde stávají jen různými formami protižidovské

Reflections on the History and Historiography of Antisemitism in Imperial Germany“. In: The Leo Baeck Institute Year Book, č. 23. London - Jerusalem - New York, Leo Baeck Institute 1978, s. 25-46.

22 Ilustrovat to mohou tvrzení typu: „Český nacionalista z nezámožných sociálních skupin by nebyl antisemitou, kdyby židé v českých zemích se svou relativní kapitálovou silou mluvili česky a podporovali český národnostní a státoprávní zápas, vyvěrající z neplnoprávnosti Čechů v monarchii (ve vztahu k rakouským Němcům) a neustálé reálné hrozby druhořadého postavení v zemi, již Češi pokládali za vlastní." (Viz KUČERA, Martin: Reakce na hilsneriádu v táboře českých radikálů. In: PAVLÁT, Leo (ed.): Hilsnerova aféra a česká společnost 1899-1999. Praha, Židovské muzeum v Praze 1999, s. 73-88.)

23 Srv. HOLZ, K.: Nationaler Antisemitismus, s. 49-111.

24 Vliv první a čtvrté konceptualizace je patrný např. v práci Michala Frankla (srv. FRANKL, Michal: Emancipace od Židů: Český antisemitismus na konci 19. století. Praha - Litomyšl, Paseka 2007). 
nenávisti (viz dále). Interpretační mř́žka přikládaná pomocí korespondenční teorie na židovské dějiny rozvrhuje společnost na znepřátelené, či přinejmenším latentně konfliktní tábory - židovskou minoritu a křestanskou, islámskou, národní (či jinou) majoritu. Obvykle se také setkáváme s různě variovaným tvrzením, či alespoň implicitním předpokladem o (vždy) odlišné identitě židů. Kritika důrazu na jedinečnost či jinakost samozřejmě neznamená, že bychom ji a priori měli odmítnout. Problém nelze postavit na dichotomii zvláštní identity a asimilace. Spočívá totiž hlouběji, v samotném obsahu pojmu židovská identita. ${ }^{25}$

\section{Trojice interpretačních schémat}

Rezignace na hlubší teoretickou reflexi a konceptualizaci výzkumu tedy souvisí s uplatněním určitého výkladového modelu. Ke slovu se zároveň s tím dostávají normativní tvrzení o historických jevech - procesech, událostech a aktérech. Základní východisko bylo stanoveno: antisemitismus se zakládá na židovské identitě - jinakosti, židovské dějiny jsou dějinami jinakosti. Jinakost, at už určená k osvojení, či popření, je v daném smyslu pouze formou naplňovanou různými obsahy, jež na tomto místě samozřejmě není možné vyčerpat. Níže uvedené typy schematických výpovědí (národ, totalita, kultura), které nám pomohou určit konkrétní podobu historického vědění operujícího $s$ dějinami obětí ve vědě a $v$ druhé části textu i v politice identity, jsou jen jedněmi z možných, byt frekventovaných zdůvodnění „zvláštního osudu“ českých židů. Navzájem se nevylučují, ba naopak uvidíme, že se v některých př́ípadech doplňují.

Při analýze nezpochybňuji přínos $\mathrm{v}$ některých případech tematicky důležitých a empiricky bohatých studií jako takových. Pouze upozorňuji na úskalí výchozích normativních tvrzení, která vědu přibližují intencím politiky identity. ${ }^{26}$

25 Spolu s kritikou teorie korespondence někdy dochází k určitému převrácení, k tvrzení, že antisemitismus nemůže souviset $s$ jednáním konkrétních židů proto, že je pouhým mýtem, potažmo ideologickou konstrukcí reality. Antisemitismus, chceme-li mluvit o mýtu, je nereálným obrazem, ale také výsledkem reálných sociálních konfliktů, v nichž židé, at už tato identita $\mathrm{v}$ daném případě znamená cokoliv, mohou vystupovat nejen jako pasivní oběti či objekty, ale i jako aktéři. Proto také nelze paušálně říci, že ti, kdo tvrdí, že židé jsou sami odpovědní či spoluodpovědní za antisemitismus, jsou antisemité. Tohoto (jinak velmi obvyklého) zjednodušení se ve zhuštěné formě dopouští např. studie: HÖDL, Klaus: Some Roots of Present-Day Anti-Semitism. In: TYDLITÁTOVÁ, V. - HANZOVÁ, A. (ed.): Reflection on Anti-Semitism, s. 15-25 (viz pozn. 11). K rozdělení antisemitismu či rasismu a stereotypního myšlení viz dále.

26 V České republice se začíná formovat badatelské prostředí pro kritičtější uchopení židovských dějin a antisemitismu, které postupně reflektuje problematická interpretační schémata, o nichž budu dále hovořit. O tom svědčí např. monotematické číslo časopisu Judaica Bohemiae (č. 2/2011) věnované především antisemitismu 19. století. Objevily se první empiricky poctivé syntézy (srv. ČAPKOVÁ, Kateřina: Češi, Němci, Židé? Národní identita Žido̊ v Čechách 1918-1938. Praha - Litomyšl, Paseka 2005 a 2013), překlad starší práce Hillela J. Kievala (srv. KIEVAL, Hillel J.: Formování českého židovstva: Národnostní konflikt a židovská společnost v Čechách 1870-1918. Praha - Litomyšl, Paseka 2012) a teoreticky i empiricky zakotvené práce o dějinách českých židů a antisemitismu (srv. TÝŽ: Languages and Community: The Jewish Experience in the Czech Lands. Berkeley - Los Angeles - London, University 


\section{Národ}

Český antisemitismus, především z doby formování národního hnutí, př́ípadně období první republiky, je některými historiky vysvětlován poukazováním na př́íklon židů k německému „vládnoucímu národu“. Odpor Čechů k židům, asimilujícím se s národním nepřítelem, je tedy představován jako součást a výsledek národnostního konfliktu. Zároveň není zcela výjimečné setkat se $s$ výkladem o vždy tolerantním př́stupu Čechů. Sem můžeme přiřadit i teze o údajně bezprecedentním zjevu asimilace židů k českému „nevládnoucímu“, „tolerantnímu“ národu. ${ }^{27}$ Tato asimilace „nesourodosti“ s národem, chápaným jako homogenní jednotka, je pak s jistou samožrejmostí posuzována pozitivně. $\mathrm{S}$ východiskem české tolerance souzní tvrzení o nerasovém (často ve smyslu „tom mírnějším“) českém antisemitismu, jenž údajně vycházel ze špatného sociálního a hospodářského postavení českého národa v 19. století a není srovnatelný s rasovým antisemitismem Němců. ${ }^{28}$

of California Press 2000; WEIN, Martin J.: Nation Cleansing and Wars of Authenticity: Czech Nationalism and Jewish Politics 1897-1952, nepublikovaná disertace, Beer Sheva 2007). Z prací českých autorů jmenujme alespoň již zmíněnou empiricky bohatou práci Michala Frankla Emancipace od Židủ či konceptuálně podnětné studie: HAMAR, Eleonóra: Vyprávěná židovství: O narativní konstrukci druhogeneračních židovských identit. Praha, Slon 2010; NOVOTNÁ, Hedvika: Židé vzpomínají na poválečná léta. In: SOUKUPOVÁ, Blanka - SALNER, Peter - LUDVÍKOVÁ, Miroslava (ed.): Židovská menšina v Československu po druhé světové válce: Od osvobození k nové totalitě. Praha, Židovské muzeum v Praze 2009, s. 107-118.

27 Srv. např. ČERNÝ, Bohumil: Vražda v Polné. In: TÝŽ (ed.): Hilsneriáda: K 100. výročí Píseckého procesu. Polná, Linda 1999, s. 15-129; k německému „vládnoucímu národu“, utlačujícímu Čechy i židy, srv. tamtéž, s. 113 nn. S korespondenční teorií, tvrzením o „bezprecedentnosti“ a s přebíráním nacionalistických narativů se někdy setkáváme i u Jana Rataje: „Rozsáhlost židovské asimilace $\mathrm{k}$ Čechům je ve srovnání s našimi sousedy výjimečná a ojedinělá i tím, že čeští židé asimilovali k národu potlačovanému. “ (Viz RATAJ, Jan: Český antisemitismus v proměnách let 1918-1945. In: TOMASZEWSKI, Jerzy - VALENTA, Jaroslav (ed.): Židé v české a polské občanské společnosti. Praha, Filozofická fakulta Univerzity Karlovy 1999, s. 45-64, zde s. 47.)

28 K rozdílu mezi „rasovým“ a „nerasovým“ v souvislosti s „národním bojem“ Čechů a Němců srv. KREJČOVÁ, Helena - MÍŠKOVÁ, Alena: Poznámky o otázce antisemitismu v českých zemích na konci 19. století. In: HOENSCH, Jörg K. - BIMAN, Stanislav-LIPTÁK, Lubomír (ed.): Emancipácia Židov-antisemitizmus - prenasledovanie v Nemecku, Rakúsko-Uhorsku, v̌̌eských zemiach a na Slovensku. Bratislava, Veda 1999, s. 45-71; GOLDSTÜCKER, Eduard: K dějinám českého antisemitismu. In: PAVLÁT, L. (ed): Hilsnerova aféra a česká společnost, s. 146-151; HERMAN, Daniel: Antisemitský časopis Brněnský drak v době hilsneriády. In: PÁLKA, Petr (ed.): Židé a Morava: Sborník z konference konané v Muzeu Kroměř́žska 13. listopadu 2002. Kroměříž, Muzeum Kroměřížska 2003, s. 232-241, zde s. 237. Tvrzení o „nerasovém“ českém antisemitismu nalezneme ovšem i v metodologicky rozpracovanějších studiích (srv. ŠTĚPÁNEK, Petr: Antisemitismus jako složka integrálního nacionalismu strany státoprávní a státoprávně pokrokové. In: Politologická revue, roč. 11, č. 2 (2005), s. 165-186). Aniž by došlo ke změně východisek metodologického nacionalismu, ocitá se někdy naopak „německý národ“ v roli tolerantnějšího národa (srv. RIFF, Michael A.: Český antisemitismus a židovská odezva před rokem 1914. In: Střední Evropa, roč. 10, č. 41 (1994), s. 52-65). K pojetí antisemitismu jako výsledku národního boje kriticky: FRANKL, M.: Emancipace od Židů, s. 8 nn. Na čtení českých židovských dějin v „nacionalistickém paradigmatu“ upozornila studie: SHUMSKY, Dimitri: Introducing Intellectual and Political History to the History of Everyday 
Národní př́běh českých dějin tímto způsobem zhodnocuje staré motivy. Češi jsou podle něj tolerantním národem vedeným svými hrdiny - především demokraty a humanisty „od Komenského po Havla“. ${ }^{29}$ Národ jako celek je obvykle stavěn do role oběti útlaku, přicházejícího vždy především zvenku (Vídeň, Němci, nacisté, Rusové, bolševici atd.).V tomto ohledu se setkáváme s velmi pevnou a trvalou narativní strukturou, využívanou v druhé půli 19. století, v padesátých letech století následujícího a občas i dnes.

Do stejné interpretační šablony patř́i i pohled historiků židovských dějin na židovskou komunitu (národ) jako na menšinu neustále perzekvovanou okolní společností. Ve zdánlivě neutrálním popisu řetězu protižidovského násilí je obsaženo zřejmé normativní, byṫ ne vždy reflektované východisko. Židé jsou tak představováni jako objekt násilí stojící uprostřed „znepřátelených táborů“ českého a německého národa. Židé jsou „zrnko drcené mezi dvěma mlýnskými kameny“, tj. Čechy a Němci. ${ }^{30}$ Explicitně tuto tezi od počátku používali a nadále použivají židovští nacionalisté coby součást argumentace dokazující nepřetržitou existenci židovského národa. ${ }^{31}$ Asimilace $\mathrm{s}$ „většinovým národem“ sice z této strany nemusí být (alespoň v českém kontextu) zcela vyloučena, není ale pozitivním východiskem soužití. V samém epicentru historického výkladu stojí národ jako obět nepřátel. Jak domnělý odpor k integraci židů, tak emigrace do Palestiny a založení národního státu či holokaust jsou považovány za logickou konsekvenci staletého vývoje a „věčného antisemitismu“.

Life: Multiethnic Cohabitation and Jewish Experience in Fin-de-Siècle Bohemia. In: Bohemia, roč. 46, č. 1 (2005), s. 39-67.

29 Dějiny tolerance mají vliv na chápání polistopadových dějin; malý výskyt soudobého antisemitismu tak lze přisuzovat návaznosti české polistopadové politické kultury na zdejší „tradice politické kultury“, tj. toleranci první republiky (NEKVAPIL, Václav: Politický extremismus a antisemitismus v České republice. In: PÁLKA, P. (ed.): Židé a Morava, s. 248-256).

30 HOZÁK, Jan: Hilsneriáda v českém tisku. In: ČERNÝ, B. (ed.): Hilsneriáda, s. 163-192, zde s. 163. Figura „židé mezi“ hraje důležitou a málo reflektovanou roli i v analýze židovských sociálních hnutí (srv. VONDRÁŠKOVÁ, Iveta: The Czech-Jewish Assimilation Movement and its Reflection of Czech National Traditions. In: Judaica Bohemiae, sv. 36. Praha, Židovské muzeum v Praze 2000, s. 143-159).

31 Typická narativní figura Judennot, původní pojem Maxe Nordaua, se velmi rychle rozšířila a stala se jedním z fundamentálních článků legitimity sionistického hnutí a nároků na uznání národních práv plynoucích právě z židovského utrpení. K pojmu Judennot a jeho roli ve formujícím se sionistickém hnutí srv. např. GAISBAUER, Adolf: Davidstern und Doppeladler: Zionismus und jüdischer Nationalismus in Österreich 1882-1918. Wien Köln/R. - Graz, Böhlau 1988, s. 82-85. K roli Judennot v českém sionistickém hnutí srv. STROBACH, Vít: Židé: Národ, rasa, třída. Sociální hnutí a židovská otázka v českých zemích 1861-1921. Praha, Nakladatelství Lidové noviny 2015, s. 166-204. Velmi komplexní dějiny utrpení Židů podává např. stat Leo Pavláta „Persekuce Židů jako historický fakt“. In: VEBER, Václav a kol.: Židé v novodobých dějinách. Praha, Karolinum 1997, s. 125-146. Eschatologie utrpení se objevuje velmi často právě i ve vztahu k holokaustu - centrálnímu místu nacionalistické verze židovské kolektivní paměti. $\mathrm{V}$ této podobě se dnes dostává také do českých pedagogických prríruček (ilustrativně viz SUCHÁ, Kateřina (ed.): Př́běhy bezpráví - holocaust: Filmy o československých dějinách, sv. 3: Metodická př́ručka. Praha, Člověk v tísni 2010, s. 6 n.). 
Za přirozený a dále neproblematizovaný základ společenské reality je v tomto výkladu pokládána společnost rozestavěná do národních celků. Tento prostor je strukturován a hierarchicky rozvrstven jazykem nacionalismu. Národní „My“ představuje obět nespravedlnosti. Oblíbená figura „židé mezi“ získává př́značnou úlohu právě v politickém jazyku národní identity, identity a priori stojící proti jiné národní identitě a vyrovnávající se s určitým nespravedlivým stavem, jenž je napravován národním bojem, emancipací či osvobozením.

První výkladové schéma můžeme nazvat metodologickým nacionalismem. Pokud s tímto schématem pracuje jak majoritní, tak minoritní výklad dějin, mohou, ale také se nemusí dostat do vzájemného konfliktu. Přestože dochází jen zřídka k důslednější revizi „dějin tolerance“ (viz výše), ${ }^{32}$ historii židovských i českých obětí se zatím dařilo spíše sjednocovat a odvracet obraz nepřítele a viníka směrem ven, mimo českou společnost a její dějiny. Jedním z důvodů je poměrně výrazné proizraelské smýšlení české veřejnosti a zjednodušující spojení mezi Izraelem a českou židovskou komunitou. ${ }^{33}$ Děje se tak i za stále funkčního a rozšířeného využití českého národního př́iběhu a přes nacionalizaci části české židovské komunity (viz dále). Ke konsolidaci dvojích, paralelních dějin obětí napomáhá druhé výkladové schéma tvořící součást společného česko-židovského horizontu historické paměti.

\section{Totalita}

Zvláště v rámci hodnocení nacistické okupace a diktatury komunistické strany v padesátých až osmdesátých letech minulého století vyniká totalitární výklad. Jeho rezidua mají nicméně vliv i na chápání předcházejících a následujících období. Vůči nim totiž „totalita“ vytváŕí negativní fólii, protiklad „přirozeného“, tedy demokratického vývoje dějin. Výzkum periody československých dějin vymezené lety 1948 a 1989, u něhož se nyní zastavím, abych na daném příkladu dokumentoval výkladovou strukturu totalitarismu, je velmi úzce spojován s totalitním panstvím komunistické strany a tematicky se koncentruje na padesátá léta, tedy období takzvaného československého stalinismu. $V$ poslední době se zpracovávají i témata spjatá s pozdějším obdobím socialistické diktatury, často ovšem se stejnými východisky. Aktéři jsou rozdělováni do dvou krajních a morálně jasně identifikovatelných táborů - mocného (zlého) režimu a bezmocné, utlačované (dobré) společnosti. ${ }^{34}$ Jaké má toto východisko důsledky pro naše téma?

32 To lze zaznamenat i v nezájmu českých historiků o holokaust, přesněji o holokaust jako inherentní součást českých dějin, a o výzkum role české společnosti v jeho uskutečňování. K českému národnímu narativu vylučujícímu téma holokaustu srv. KOLÁŘ, P. - KOPEČEK, M.: A Difficult Quest for New Paradigms, s. 209 n. a 226 (viz pozn. 6).

33 Srv. BLAIVE, Muriel: The Memory of the Holocaust and of Communist Repression in a Comparative Perspective, s. 162-165 (viz pozn. 3).

34 Ke kritice totalitárního diskurzu v české historiografii srv. PULLMANN, Michal: Diktatura, konsensus a společenská změna: K výkladu komunistické diktatury v českých akademických diskusích po roce 1989. In: STORCHOVÁ, Lucie-HORSKÝ, Jan (ed.): Paralely, průsečíky, mimoběžky: Teorie, koncepty a pojmy v české a světové historiografii 20. století. Ústí nad Labem, 
Morálně závadný antisemitismus získává v historických pracích podobu přirozeného prvku panství komunistické strany, součásti mocenských praktik „zlého režimu“. „Dobrá společnost“ je naproti tomu neantisemitská, př́padně antisemitismem „infikovaná shora" pomocí rozličných nástrojů symbolické moci (komunistické propagandy), jimiž (antisemitský) režim disponoval. Představa „nakažení shora“ je dotvářena zdůrazňováním podřízenosti československého státu „vyšším zájmům“. Při popisu antisemitské totalitní moci se objevují metonymie (Moskva, Kreml), personifikace (Stalin), v roli jejích nositelů vystupují sovětští poradci. Antisemitismus se zdá být jakýmsi vývozním artiklem Moskvy, respektive Stalina do východního bloku. Setkáváme se např́klad s charakteristickou metaforou „vlny antisemitismu“, přelévající se východní Evropou podle potřeb komunistických elit. Stalina (Moskvu, Sověty...) pak vidíme pomocí antisemitských politických procesů utužovat loajalitu místních komunistických vládců, ovládajících zase - i díky antisemitismu - (dobrou) společnost. „Vlna antisemitismu“ spolu s cíleným a jednosměrným přenášením antisemitismu shora dolů odpovídá prezentovaným mechanismům totalitní moci. ${ }^{35}$ Samotné pojetí antisemitismu, za nímž se údajně skrývají skutečné zájmy mocných, zcela zapadá do totalitárního výkladu.

Židé jsou v tomto příběhu dějin popisováni jako jedna z prvních obětí nového režimu a samotný symptom destrukce normálních poměrů. Uved’me alespoň jednu z typických podob takového výkladu. Po přetvářce komunistů, ujištujících židy o respektu k jejich právům, se po únoru 1948 vyjeví skutečný, antisemitský obsah komunismu. „Židovské obyvatelstvo republiky však nemuselo čekat ani do počátku padesátých let, kdy se s politickými procesy zvedla nová vlna antisemitismu, aby k takovým ujištováním a slibům cítilo opodstatněnou nedůvěru, " píše se v jedné z prvních polistopadových publikací $\mathrm{k}$ tématu. ${ }^{36}$ Setkáváme se také s termíny „latentní antisemitismus“ či „antisemitské tendence“. Antisemitismus je líčen dokonce jako esence komunismu, což logicky vyústuje v čistky a procesy. ${ }^{37}$ „Antisemitismus ... nebyl specifickým rysem komunistického režimu, ale jeho rysem integrálním,

Albis international 2009, s. 231-246; TÝŽ: Konec experimentu: Přestavba a pád komunismu $v$ Československu. Praha, Scriptorium 2011.

35 Viz např. PEJČOCH, Ivo: Politické procesy s Šimonem Ornsteinem a Mordechajem Orenem - antisemitské tendence v komunistickém Československu. In: Terezínské listy, č. 39. Terezín - Praha, Památník Terezín - Nakladatelství Oswald 2011, s. 142-153, zde. s. 142; SVOBODOVÁ, Jana: Zdroje a projevy antisemitismu v českých zemích 1948-1992. Praha, ÚSD AV ČR 1994, s. 20 nn. Za vlivné lze i v tomto směru označit práce Karla Kaplana; k jeho výkladu o antisemitském komunistickém režimu, jenž pracuje i s metaforou „vlna antisemitismu“, srv. KAPLAN, Karel: Československo a Izrael v letech 1947-1953. In: DUFEK, Jiří - KAPLAN, Karel - ŠLOSAR, Vladimír: Československo a Izrael v letech 1947-1953. Praha, ÚSD AV ČR - Doplněk 1993, s. 8-103, zde s. 81-103.

36 SVOBODOVÁ, J.: Zdroje a projevy antisemitismu $v$ českých zemích 1948-1992, s. 21.

37 Srv. HOŠEK, Pavel: Osud židovských komunistů v socialistickém Československu: Př́padová studie. In: TYDLITÁTOVÁ, Věra (ed.): Kolokvium o soudobém antisemitismu, sv. 2. Plzeň, Adela - Grafické studie 2008 s. 81-89. 
nevyhnutelným, tak jako jím byl a je v každé ideologii postavené na nenávisti a praktikované totalitní mocí, "čteme ve zmíněné publikaci. ${ }^{38}$

Sémantické propojení pojmů demokracie - normální -židé a na druhé straně totalitarismus - nenormální - antisemitismus se zdá být zcela přirozené, odpovídá a naplňuje obsahem dichotomii „dobrá společnost“ - „zlý režim“. Komunistický antisemitismus slouží k dokreslování nelidskosti totality, jež nemá nic společného s normálním, tedy komunisty neznásilněným průběhem českých dějin. Právě v rámci tohoto výkladu se setkávají dvě kompatibilní figury obětí, česká a židovská. V totalitárním schématu, či řekněme metodologickém totalitarismu, jsou židé, ale právě i Češi, definováni jako oběti nacismu a komunismu. Léta 1938/1939 až 1989 jsou bezešvou periodou pokračující represe, přerušovanou nanejvýš obdobím třetí republiky a pražským jarem 1968. Židé i česká společnost přitom bývají vykreslováni v roli pasivních aktérů na cizím (nacistickém/německém, komunistickém/sovětském) mocenském poli.

Slovník totalitarismu tedy hraje výraznou roli v „plačtivých dějinách“, kladoucích akcent na pronásledování ze strany nacistické a komunistické totality coby důsledek pokračujícího řetězu odvěké protižidovské nenávisti. Aktivní jednání židů ve stranických, represivních a jiných mocenských strukturách, či jen souhlas s poúnorovým politickým systémem jsou v tomto schématu bud' vyloučeny, odsouvány na samotný okraj pozornosti, či automaticky obhajovány jako dočasné vybočení. ${ }^{39}$ Za projevy antisemitismu jsou v období 1948 až 1989 pokládány skutečně rasistické praktiky typu odkazování na takzvaný židovský původ odsouzených špiček komunistické nomenklatury během politických procesů padesátých let a monitorování židovské populace jako „státně nespolehlivé“ v letech padesátých a sedmdesátých. Někteř́ autoři za antisemitismus ovšem vydávají i takzvanou komunistickou politiku asimilace či nezájem komunistů o židovskou kulturu. ${ }^{40}$ Problém sám o sobě pak představuje propagovaný antisionismus, který je považován výhradně za nositele skrytého antisemitismu, tedy přirozeného nepřátelství, aniž by byl kontextuálně

38 SVOBODOVÁ, J.: Zdroje a projevy antisemitismu v českých zemích 1948-1992, s. 53; zvýrazněno $v$ originálu.

39 I jinak vi̊či schématům totalitarismu poměrně ostražití autoři jako Blanka Soukupová, dokazující ve svých studiích i aktivní formy jednání židů v poúnorové společnosti a různých veřejných grémiích, se poněkud nekoherentně uchylují k paušálním tvrzením na adresu všech či většiny židů, aniž by k tomu měli relevantní prameny: „Do roku 1948 tedy vcházeli českoslovenští Židé, přes negativní zážitky s antisemitismem, ještě plni nadějí. Únor je z velké části pohřbil." (SOUKUPOVÁ, Blanka: Židé a židovská reprezentace v českých zemích v letech 1945-1948: Mezi režimem, židovstvím a judaismem. In: SOUKUPOVÁ, B. - SALNER, P. LUDVÍKOVÁ, M. (ed.): Židovská menšina v Československu po druhé světové válce, s. 55-80, cit. s. 77.) Podobně vyznívá věta: „Vystřízlivění s sebou přinesly zpravidla až politické procesy na konci čtyřicátých let a na počátku padesátých let 20. století.“ (SOUKUPOVÁ, Blanka: Modely životních osudů českých Židů po šoa. In: Tamtéž, s. 81-106, cit. s. 88.)

40 Srv. PODLEŠÁK, Jan: K otázkám genocidy českých Židů, komunistického antisemitismu a záchrany židovských památek. In: RYBÁR̆, Radovan - VALACH, Milan (ed.): Totalitarismus ve 20. století: Československé zkušenosti. Brno, Masarykova univerzita 2001, s. 172-186; SVOBODOVÁ, J.: Zdroje a projevy antisemitismu v českých zemích v letech 1948-1992, s. 65 nn. 
rozlišen rasistický podtext antisionismu a antisionismus v podobě legitimního nesouhlasu s určitým politickým projektem. ${ }^{41}$

Pojmu „antisemitismus“, sloužícímu jako součást morálního odsouzení komunistického režimu, chybí analytická relevance. Přispívá k obsahové vyprázdněnosti metodologického totalitarismu a jeho neschopnosti napomoci porozumění sociálním procesům a individuálním motivacím, spojeným mimo jiné se zásadní otázkou utváření společenského konsenzu v období socialistické diktatury. „Totální“ viktimizace židů se dobře doplňuje $s$ antikomunistickým prŕběhem identity současné pravicově liberální a konzervativní politické části veřejnosti, a to zvláště tam, kde se východiska totalitarismu a nacionalismu pojí. I zde je eventuálně možný konflikt normativních výkladů dějin. Konsenzus se může rozpadat, pokud bude na jedné straně zpochybněna perzekuce židů za druhé světové války jako výhradní záležitost nacistů (Němců) a zváží-li se aktivní účast české společnosti na tomto konání-a pokud se na druhé straně připustí aktivní role židů ve strukturách „zlého režimu““. ${ }^{42}$ Tato eventualita, objevující se zatím ve zcela okrajových veřejných a vědeckých diskurzech, odhaluje jedno z nebezpečí uvedeného schématu a nevhodnost jeho kategorií, mezi nimiž získala obět důležité místo. Oběti, jak podotýká Esther Benbassová, si totiž mohou lehce vyměnit místo. ${ }^{43} \mathrm{~V}$ daném prŕípadě mohou být židé při takovéto výměně rolí dokonce obžalováni z propagace komunismu a chápáni jako nositelé národu nebezpečných myšlenek; s těmito názory se dosud setkáváme především na neonacistických webech a fanzinech.

\section{$\underline{\text { Kultura }}$}

Dva dosud zmíněné přístupy rozšírím ještě o třetí, který v jistém smyslu doplňuje a zároveň propojuje interpretační rámec. Dalším z kvaziautonomních diskurzů, který se zapisuje do historiografické produkce, je liberální humanismus, potažmo multikulturalismus. Pro něj jsou charakteristická další normativní a konceptuální východiska. Za hlavní problém určité kultury, ideologie, názoru je

41 Srv. ARAVA-NOVOTNÁ, Lena: Od antisemitismu k antisionismu: Československo po roce 1948. In: MACHAČOVÁ, Helena (ed): První pražský seminář: Dopady holokaustu na českou a slovenskou společnost ve druhé polovině 20. století. Praha, Varius Praha - Spolek akademiků Židů 2008, s. 85-95. K analogii antisionismu a antisemitismu se uchyluje i Klaus Holz v analýze politického procesu s Rudolfem Slánským (viz HOLZ, K.: Nationaler Antisemitismus, s. 431-482 - viz pozn. 20). Rovnítko mezi antisemitismus a antisionismus dávají bez dalšího vysvětlení a analýzy obvykle také autoři, kteří se jinak dějinami židů či antisemitismem nezabývají (srv. KŘEN, J.: Bílá místa v našich dějinách?, s. 82 n. - viz pozn. 8).

42 Dějiny židů a /jako dějiny antisemitismu se líčí coby dějiny utrpení v „komunistické totalitě“ např. v následujících publikacích: SVOBODOVÁ, J.: Zdroje a projevy antisemitismu $v$ českých zemích v letech 1948-1992; BROD, Petr: Židé v poválečném Československu. In: HOENSCH, J. K. - BIMAN, S. - LIPTÁK, L. (ed.): Emancipácia Židov - antisemitizmus - prenasledovanie $v$ Nemecku, Rakúsko-Uhorsku, $v$ českých zemiach a na Slovensku, s. 177-189 (viz pozn. 28); PAVLÁT, Leo: Antisemitismus - nejtrvalejší zášť v dějinách lidstva. In: TÝŽ (ed.): Židé: Dějiny a kultura. Praha, Židovské muzeum v Praze 2005, s. 83-110, zde s. 104 nn.

43 BENBASSA, Esther: Suffering as Identity: The Jewish Paradigm. London, Verso 2010, s. 178. 
považována (kulturní) netolerance. ${ }^{44}$ Antisemitismus v daném kontextu vytváŕí měřítko (ne)kulturnosti společnosti, nehumánnosti ideologií, př́padně patologického projevu jedinců, např́klad osobností politického života. Kulturnost, respektive kultivovanost a tolerance jsou naopak vysvědčením vyspělosti společnosti (státu apod.). Než přistoupím v poslední kapitole („Mezi politikou vědy a identity“) k prozkoumání možného úskalí multikulturního přístupu v jeho znehodnocené podobě, budu se věnovat druhému vytčenému problému této studie. Závěrečná část by pak měla pomoci uchopit komplementaritu politiky vědy a identity/paměti.

\section{Politika identity}

\section{Národ a jeho oběti}

Na začátku jsem zmínil důležitost figury oběti v artikulacích boje o uznání. Jak upozorňují badatelé z okruhu memory studies, je to teprve situace evropských zemí od šedesátých let dvacátého století, kdy se „pasivni““, „nevinná“ obět stává základní komponentou těchto bojů. ${ }^{45}$ Současná podoba „plačtivého př́íběhu“ židovských dějin je na jednu stranu typickou součástí tohoto jevu - holokaust židů se koneckonců stal jakýmsi paradigmatem kolektivní oběti - ale má také svá specifika a hlubší kořeny. Na tomto místě lze jen stručně shrnout nejvážnější problémy, které dějiny věčných obětí přinášejí a jež ovlivňují politiku židovské identity. Již dříve před jejich rezidui varovala Hannah Arendtová, Zygmunt Bauman a jiní, z historiografické obce např́íklad Shulamit Volkovová. ${ }^{46}$

Spolu s Arendtovou lze hovořit o výkladu, respektive narativu vycházejícím ze starého náboženského a později (mimo jiné) židovskými nacionalisty racionalizovaného mýtu vyvolení. Tito nacionalisté přistoupili $\mathrm{k}$ tradici vyvolení jedním ze způsobů, které judaismus umožňoval. Arendtová při kritice „plačtivých dějin“ upozorňuje na nadřazování židovského náboženství, jako by vždy prosazovalo toleranci a lidskou rovnost. „Sebeklamná teorie,“ dodává Arendtová, „doprovázená přesvědčením, že židovský národ byl vždy pasivním trpícím objektem křestanského pronásledování, vlastně přispěla k přežití a modernizaci starého mýtu o vyvolenosti a nezbytně vedla $\mathrm{k}$ novým a často velice komplikovaným metodám vydělování, které potvrzovaly starověkou dichotomii. “47 $\mathrm{S}$ židy (Židy) trpícími přišli židé bojující,

44 To je patrné i v konceptu kultivace, úzce spojujícím toleranci s myšlením českých liberálů (realistů), resp. s liberálnědemokratickým prostředím první republiky (srv. SOUKUPOVÁ, Blanka: Český antisemitismus jako dekultivace češství (1890-1938). In: MACHAČOVÁ, Jana - MATĚJČEK, Jiří - SOUKUPOVÁ, Blanka (ed.): Studie k sociálním dějinám. Praha, Fakulta humanitních studií Univerzity Karlovy 2004, s. 128-137).

45 Srv. HALlaMA, P.: Geschichtswissenschaften, Memory Studies und der Passive Turn (viz pozn. 3).

46 ARENDTOVÁ, Hannah: Dějiny totalitarismu, sv. 1-3. Praha, Oikoymenh 1996, s. 14 nn.; VOLKOV, Shulamit: Germans, Jews and Antisemites: Trials in Emancipation. New York, Cambridge University Press 2006, s. 67 nn. a 159 nn.; k Baumanovi viz dále.

47

ARENDTOVÁ, H.: Dějiny totalitarismu, s. 15. 
$s$,židem ghetta“ se představil „žid Masady“. Př́běh kombinující figury oběti a bojovníka je pro zrod a fungování nacionalistických hnutí celkem obvyklý a nemůžeme ho připsat výlučně sionismu. Jestliže obět vystupuje při obhajobě pošlapaných, zneuznaných práv národa, bojovník mobilizuje národní hnutí proti agresorům; oba tedy neoddělitelně koexistují. ${ }^{48}$

Zásadní, formativní úlohu pro chápání židovských dějin jako dějin obětí měla a má otázka (dis) kontinuity středověkého a moderního antisemitismu, respektive schopnost samotného termínu „antisemitismus“ propojit různé formy protižidovského násilí. Zygmunt Bauman v knize Modernita a holokaust roztř́́dil to, co bylo a stále někdy bývá považováno za identické. Varoval před směšováním kvalitativně odlišných jevů antisemitského rasismu a heterofobie. Rasismus, stojící u zrodu projektu moderních genocid, označuje skupiny lidí endemicky a beznadějně odolávajících kontrole, imunních vůči snahám o „zušlechtění“. Proto ovšem institucionalizovaný antisemitský rasismus, až do podoby vyhlazovacího průmyslu, nelze zaměňovat za žádnou formu „starého“ náboženského, politického či jiného nepřátelství ani jej srovnávat s úzkostmi moderního člověka promítanými do odlišných „druhých“ uvnitř společnosti. Mezi těmito dvěma jevy, ř́ká Bauman, ve skutečnosti neexistuje žádná př́má návaznost. ${ }^{49}$ Ahistorický výklad holokaustu, abstrahující od souvislostí moderního rasismu, byrokratického řízení společnosti a státu a podobně - tedy jevů nemajících a priori s protižidovskou nenávistí nic společného - je umožněn mimo jiné podáním židovských dějin jako dějin antisemitismu. Bauman odmítá „privatizaci“ holokaustu, podle níž je daný jev popisován jako záležitost „židů a těch, kdo je nenávidí“. K tomuto postoji přidává „sakralizaci“ holokaustu, pomáhající zachovat jedinečnost a nesrovnatelnost židovského utrpení. Holokaust se v důsledku jeví jako jedinečná, nesrovnatelná, ale proto také analyticky neuchopitelná a nereprezentovatelná událost, jež patří výlučně k dějinám židovského národa.

Explicitní či implicitní odkazy k věčnosti, nevykořenitelnosti, neměnnosti jevu, jakým údajně antisemitismus je, zamlžují možnosti relevantní analýzy protižidovského násilí - zasazeného do historického času a kontextu - a pomáhají reprodukovat mýtus vyvolení. Kolektivní pamět strukturovaná „podél“ věčného antisemitismu umožňuje aktérům pochopit a zároveň esencializovat nenávist okolního světa vůči

48 Transfiguraci „obět'-bojovník“ v sionistickém narativu na konkrétních příkladech (např. Varšavské povstání, proces s Adolfem Eichmannem aj.) dobře vyložila Idith Zertalová v práci Israel's Holocaust and the Politics of Nationhood (Cambridge, Cambridge University Press 2005). Obět i bojovník se nejintenzivněji objevují ve fázi nacionalismu, kterou John Hutchinson nazývá hot-nationalism; ten operuje s pevnou národní identitou, svátostí národa a dostává se ke slovu v obdobích politických krizí. Naopak banal-nationalism je udržovaný komemorativními akty, jejichž kapacita je zkoušena bojem vyloučených skupin o uznání. Pokud boje za uznání sílí, jsou omezovány třídní, rodinné a jiné identity a „banální“ fázi obvykle opět střídá její „horký“ souputník. (Viz HUTCHINSON, John: Nations as Zones of Conflict. London, Sage 2005, s. 152 n.)

49 Srv. BAUMAN, Zygmunt: Modernita a holocaust. Praha, Sociologické nakladatelství 2003, s. 109 nn. Ztotožnění heterofobie a rasismu, dodává Bauman, odvádí pozornost od hlavních problémů, od aspektů moderní mentality a sociální organizace. V těch tkví jádro rasismu, nikoliv v odvěkém nepřátelství k cizincům či v konfliktech o identitu. (Viz tamtéž, s. 131.) 
židovské komunitě, potažmo vůči „židovskému státu“. V př́padě Izraele přispívá k legitimizaci institucionalizovaných vztahů uznání a vyloučení na základě etnocentrických právních a sociálních norem („právo návratu“, občanská práva, vojenská služba aj.)..$^{50}$ Zároveň není náhodou, že si právě izraelští židovští „novi“ historikové a historičky (Ilan Pappé, Shlomo Sand, Avi Shlaim, Idith Zertalová ad.) od osmdesátých let uvědomují nebezpečí a ostře kritizují narativ oběti ve službách nacionalismu. ${ }^{51}$ Nezpochybňují nárok Izraele na suverenitu, jak tvrdí někteří jejich kritici, ale dějiny obětí, tento konstitutivní prvek etnocentrického nacionalismu, jenž zvyšuje konfliktnost (nesouladnost) pamětí na obou stranách bariéry mezi palestinským a židovským obyvatelstvem, přiživované konzervativními, fundamentálně náboženskými a nacionalistickými elitami. V Izraeli tedy existuje do jisté míry zakotvená „historická škola“, která odporuje hegemonickému sionistickému výkladu dějin.

Dále se budu zabývat tím, jak výpovědi, o nichž jsem pojednával při rozboru historiografie, vstupují do veřejné diskuse o antisemitismu v českém prostředí. Na konceptu takzvaného nového antisemitismu, jenž získává v posledních letech důležitý vliv, v kritice politologa Pavla Barši i v proměně veřejného života židovské komunity lze rozpoznat uplatnění nacionalistického a totalitárního diskurzu. Dủležité pojítko nakonec vyvstane v podobě kulturalismu.

\section{Nový antisemitismus ve „3D“ - depolitizace politického}

Pomocí „univerzalizujících“ pojetí antisemitismu je za antisemitské možné označit různé osoby i velmi heterogenní sociální a politické skupiny, historické i zcela současné jevy. Na př́́kladu „nového antisemitismu“, jehož hlavními nositeli jsou údajně levicová hnutí a arabští, respektive muslimští přistěhovalci do Evropy, se ovšem ukazuje, že se namísto analytických pojmů, dovolujících adekvátně popsat podoby protižidovského nepřátelství, dostavuje naturalizace nepřátelství, snaha postavit určité politické názory mimo svět politických kategorií (v logice přítel versus nepř́tel), do světa esenciálních identit a jejich vzájemných konfliktů a morálně-teologických pojmů (věčně dobrý/zlý). Tato depolitizační strategie je přitom vlastní rasistickým antisemitům (od př́rody zlý žid), etnocentrickým nacionalistům (přirozený, tj. nepolitický národ spř́izněný krví, půdou atd.), ale i určité myšlenkové tradici liberalismu. Konzervativní německý politický filozof Carl Schmitt poznamenává, že liberálové sice státu vytýkají používání násilí, ale ve skutečnosti jejich koncept vládnutí od násilí neupouští. Válka zůstává, jen se z ní stává permanentní konkurence, falešný univerzalismus ekonomických norem, fungujících podle liberálů v zájmu lidského pokroku. Války, které jsou v tomto duchu vedeny, jsou „válkami za mír“, „posledními

50 Srv. ČEJKA, Marek: Izrael a Palestina: Minulost, současnost a směřování blízkovýchodního konfliktu. Brno, Centrum strategických studií 2005, s. 95 nn.; PERI, Yoram: Between Battles and Ballots: Israeli Military in Politics. Cambridge, Cambridge University Press 1983, s. 19-38.

51 Kjejich ,programu“ srv. PAPPÉ, Ilan: Fifty Years Through Eyes of "New Historians" in Israel. In: Middle East Report, č. 207 (1998), s. 14-17 a 23. 
válkami“, aby se už žádné další nemusely vést. ${ }^{52}$ Zvítězit samozřejmě musí „pokrok“, který je reprezentován pokrokovými, civilizovanými, dobrými národy v konfrontaci se zaostalými a zlými barbary. Zvláště dnes je v artikulacích kolektivních identit nezbytné sledovat prolínání „starého“ diskurzu nacionalismu s „novou“ (neo)liberální argumentací ekonomického výkonu, pokroku a podobně a s jistým druhem humanismu (viz dále).

Koncept „nového antisemitismu“ se stále silněji uplatňuje i v tuzemské diskusi. ${ }^{53}$ V pojetí jeho zastánců, přestože se v detailech rozcházejí, zůstává jádro „starého“ i „nového“ antisemitismu prakticky stejné. Odlišná je pouze forma, přičemž samotná „novost“ podle stoupenců daného výkladu spíše potvrzuje nevykořenitelnost „věčného antisemitismu“. Tvrdí, že namísto útoků na židovskou rasu, považovaných od druhé světové války většinovou společností za nelegitimní, se útočí na zástupný objekt: Izrael. Pod rétorickými strategiemi islámských radikálů, pravicových i levicových kritiků Izraele se prý skrývá „skutečný obsah“ výpovědí, a to nenávist vůči celému židovskému národu. Tato teze mívá i poněkud sofistikovanější podobu. Hovoří se např́íklad o legitimní kritice izraelské politiky, která jako vedlejší, či snad přímo nechtěný efekt reprodukuje nelegitimní výpovědi, tj. tradiční stereotypy a antisemitismus. ${ }^{54}$

Tradiční stereotypy, „starou zlobu“, údajně vnášejí do veřejného prostoru všichni, kteří při své kritice Izraele spadají do jedné z kategorií „3D“ schématu Natana Šaranského, konzervativně nacionalistického politika strany Likud, proslulého svými rasistickými poznámkami na adresu Palestinců. První „D“ vyjadřuje dvojí metr, odlišné parametry kritiky při hodnocení Izraele a jiných států; druhé „D“ znamená démonizaci Izraele, např́íklad jeho srovnávání s nacistickým Německem (a utlačování Palestinců s holokaustem), kritiku jeho mezinárodního mocenského postavení (vliv na USA) a podobně. Posledním „D“ je delegitimizace, odmítnutí přiznat židům (Židům) stejná práva na národní suverenitu, jaká jsou přiznána jiným národům. Důležité je tvrzení, že se tři roviny „nového antisemitismu“ vyskytují vedle sebe a navzájem se řetězí. Pokud tedy u zkoumaného objektu zaznamenáme jedno „D“, má to signalizovat př́tomnost celého antisemitského „komplexu“.

52 Viz SCHMITT, Carl: Pojem politična. Praha, Oikoymenh 2007, s. 72 nn. Ti, kteří mají ekonomickou moc, doplňuje Schmitt, označují každý pokus o „mimoekonomickou“ změnu jejich postavení ze strany vykořistovaných jako akt násilí a zločinu (tamtéž, s. 76).

53 Tématem „nového antisemitismu“ se profilují např. zmíněné sborníky z produkce Západočeské univerzity v Plzni (srv. TYDLITÁTOVÁ, V. - HANZOVÁ, A. (ed.): Reflection on Anti-Semitism (viz pozn. 11); TYTÉŽ (ed.): Anatomy of Hatred (viz pozn. 11); BUDIL, I. ARAVA-NOVOTNÁ, L. - TYDLITÁTOVÁ, V. - TARANT, Z. (ed.): Nová doba, stará zloba (viz pozn. 11)). K propojení konceptu „3D“ a „nového antisemitismu“ srv. např. KALLUS, Mojmír: Current Trends of anti-Semitism in Europe. In: TYDLITÁTOVÁ, V. - HANZOVÁ, A. (ed.): Anatomy of Hatred, s. 102-106.

54 To je typické i pro práce Emanueleho Ottolenghiho a Waltera Laqueura (srv. LAQUEUR, Walter: Měnící se tvář antisemitismu: Od starověku do dnešních dnů. Praha, Nakladatelství Lidové noviny 2008; OTTOLENGHI, Emanuele: Autodafé Evropa: Židé a antisemitismus. Praha, Academia 2012 (viz dále)). 
Třetí „D“ lze chápat coby jeden z prvků soustavy, ale i jako to, co ji determinuje ve svém celku. Umožňuje za antisemitské označit všechny námitky proti ,jediné demokracii Předního východu“, národnímu státu (Izraeli), tomuto specifickému politickému projektu evropské moderny, včetně jeho etnocentrické politiky. ${ }^{55}$ Velmi přesně to vyjádřil ředitel Židovského muzea v Praze Leo Pavlát, poté co po vzoru Šaranského definoval první dvě „D“: „A [Šaranský] dodává ještě třetí antisemitské „D“: snahy delegitimovat židovský stát jako takový, upřít židovskému národu právo na státnost. Právě to je pravým obsahem antisionismu, mezi jehož propagátory najdeme - pro někoho možná překvapivě - Izraelce i potomky rodin s židovskými kořeny.“56 Analytický nástroj, jakým má být „,3D“, tedy v žádném případě nelze považovat za politicky neutrální, stejně jako slova o kriticích $s$ „židovskými kořeny“" (viz dále). Nejméně ze všeho tento nástroj umožní identifikovat skutečně rasistické, antisemitské názory a chování.

\section{Čeští židé proti „novým antisemitům“}

„Nový antisemitismus“, dokládaný modelem „3D“, představuje podle některých autorů důležitou výzvu multikulturnímu soužití, toleranci a demokracii. Pojem, a především diskuse, která se s novou naléhavostí rozviŕila po takzvané druhé intifádě a útoku na newyorská obchodní centra v roce 2001, ilustruje pojetí (etnocentrické, nacionalistické) kolektivní identity, kterou, at už vědomě, či nevědomě, přijímá část akademické veřejnosti a české židovské komunity jako přirozenou. ${ }^{57}$ V posledních zhruba deseti letech tento fakt dobře dokumentují reakce na texty Pavla Barši, jejichž přičiněním se Barša ocitl v roli gurua levicově akademického „nového antisemitismu“. Bez ohledu na to, do jaké míry se Baršovi daří vysvětlit proměnu interpretací a kolektivní paměti holokaustu v poválečné historii, spojit odlišné perspektivy a poskytnout východiska letitého sporu, je charakteristické, $\mathrm{s}$ jak vyhrocenou reakcí se jeho názory setkávají. ${ }^{58}$

55 Ti, kdo hájí koncept „nového antisemitismu“, přitom berou za nezpochybnitelný fakt náchylnost antisemitů $\mathrm{k}$ antisionismu a naopak. Odhlížejí od posunu v evropském a americkém ultrapravicovém táboře. Mnozí čeští (a evropští) rasisté a xenofobové fandí ve svém strachu z „islámské hrozby“ a „střetu kultur“ (viz dále) islamofobnímu zaměření současných pravicově konzervativních izraelských vlád a represivním postupům vůči Palestincủm. U nás tento hlas ultrakonzervativní, xenofobní a proizraelské pravice asi nejlépe reprezentuje portál Eurabia, online dostupné z: http://eurabia.parlamentnilisty.cz/Default. aspx [cit. 2016-10-21].

56 PAVLÁT, Leo: Izrael na pranýři levice. In: Lidové noviny (13.10.2012), s. 4.

57 Koncept „nového antisemitismu“ přejímají např. někteří badatelé věnující se současnému levicovému či akademickému antisemitismu (srv. TYDLITÁTOVÁ, Věra: Akademický antisemitismus. In: BUDIL, I. - ARAVA-NOVOTNÁ, L. - TYDLITÁTOVÁ, V. - TARANT, Z. (ed.): Nová doba, stará zloba, s. 99-127). Obecně ke kritice pojmu „nový antisemitismus“ srv. BARŠA, Pavel: Nový antisemitismus, či co... V Evropě a Americe se diskutuje o ,,nové judeofobii“. Jaké jsou její příciny? In: Lidové noviny (28.2.2004), s. 13 a 15.

58 Pavel Barša poukázal na ty skupiny v Izraeli a USA, jež mají zájem na „fetišizaci traumatu“, fenoménu holokaust v kolektivní paměti židů (srv. Baršův doslov ke knize Normana Finkelsteina Průmysl holocaustu: Úvahy o zneužívání židovského utrpení. Praha, 
„Také fakt, “ čteme v jedné recenzi Finkelsteinovy knihy, jež vyšla v profilovém periodiku Federace židovských obcí Roš chodeš, „že docent Pavel Barša ... není objektivním interpretem, schopným zhodnotit Finkelsteinův význam (či spíše tezi o zneužívání šoa obecně), je zřejmý při četbě jeho doslovu. Barša vystudoval FF UJEP v Brně, obor marxisticko-leninská filosofie - politická ekonomie (absolvoval roku 1984), a ve výkladu tuto erudici nezapře. (...) Rozehrává-li Finkelstein škálu obvinění a osobních útoků, dodává jim Barša ideologický, marxistický rámec. “59 $\mathrm{K}$ delegitimizaci názoru v tomto př́padě postačil odkaz $\mathrm{k}$ „původu“ politologa (studium „marxisticko-leninské filosofie“) a k marxismu. Krom velmi nekritického přijetí narativu (národního) utrpení, s nímž se v diskusi z této strany obvykle setkáváme jako s formativním prvkem židovské identity, se ke slovu dostává totalitární výklad. ${ }^{60}$

I další Baršův kritik dokazuje jeho „nakaženost“ totalitní ideologií. Obviňuje ho z antisemitismu, či přinejmenším z jeho přehlížení. Jeho slova přitom dobře ilustrují totalitární interpretační schéma v kontextu výpovědí o „věčném antisemitismu“. Dílčí politické názory antisemitů se mění, zatímco antisemitismus jako jev zůstává stejný: „Pomocí různých zavádějících černobílých protikladů je vymezován kolektivní Žid (sionista, sionismus), který pod různými jmény (žid. organizace, američtí Židé, Stát Izrael, izr. instituce) působí jako záporný agens. “61 Strategická kamufláž „skutečných názorư“, skrývajících totalitářské sklony a projevy nenávisti, pomáhá obhájit nemorální chování: „Jmenování opačného pólu, menšiny jednotlivých Židů, pokrokových humanistů a liberálů, kteří jsou disentem Žida, autora chrání př̀ed

Dokořán 2006, s. 107-125). Později se pokusil rozvést a obhájit určitou normativní, střední cestu reprezentace a připomínání genocidy židů. Nabídl řešení sporu mezi zastánci zákazu reprezentace šoa a nedotknutelnosti jedinečného židovského utrpení a mezi těmi, kdo vysvětlují a ukazují holokaust jako univerzální problém a symptom krize moderní společnosti. Odmítl jak politiku „prázdné“ holokaustové identity prosazované izraelskými a americkými konzervativními elitami, tak univerzalismus, jenž v Baršově interpretacích sice umožňuje dialog a respekt k utrpení druhého, ale také asimilaci a zneuznání obětí. 'Srv. BARŠA, Pavel: Pamět a genocida: Úvahy o politice holocaustu. Praha, Argo 2011.) Již o několik let dříve se čeští čtenáři mohli s kritickou reflexí reprezentace a paměti holokaustu seznámit díky kvalitnímu příspěvku filozofa Martina B. Matuštíka „Vydávání svědectví a otázka uznání v antivykupitelské době: Vyhlazované národy a náš problém uchování paměti“ ve Filosofickém časopise (roč. 50, č. 5 (2002), s. 811-830).

59 Viz MARXOVÁ, Alice: Finkelsteinova argumentace nenávisti. In: Roš chodeš, roč. 68, č. 5 (2006), s. 8 a 11, cit. s. 11.

60 Obojí lze dobře vidět např. na tomto citátu: „Domnívat se, že profesor Karlovy univerzity neví, že během holokaustu nebyli Židé zabíjeni jako 'jedinci', ale jako členové 'partikulární skupiny' bez ohledu na to, zda k ní patřili sionisté nebo ne, jistě nelze. Židovskému národu vyčítá, co by v jiném př́ípadě nejspíš uznal: Že totiž každý národ reflektuje svou historickou zkušenost a jedná v souladu s ní. (...) Pavel Barša nalezl v holokaustu své téma a ž̌ejmě se ho hned tak nezřekne. Avšak: Neřadí se tak vlastně po bok lidem, kteří podle něj z holokaustu a paměti na něj profitují? Nestal se už i on sám součástí jím tolik opovrhovaného 'průmyslu holokaustu'?“ (TÁŽ: Kontroverzní kniha „Pamět a genocida“. In: Český rozhlas [online]. 22. května 2011 [cit. 2016-09-20]. Dostupné z: http://www.rozhlas.cz/nabozenstvi/zpravy/zprava/896173.)

61 CHÁB, Viktor: Ještě k novému antisemitismu. In: Roš chodeš, roč. 68, č. 7 (2006), s. 15. 
podezřením z antisemitismu. Žid spolu s vládou USA, která je pod vlivem mocné židovské lobby, jsou třídou vládnoucí světu proti jeho internacionalistickým, humanistickým, multikulturním či socialistickým zájmům. “62 Souhrnné sdělení těchto a dalších článků by mohlo znít: totalitní ideologie antisemitů souvisí s nemravností autora, respektive aktéra. Barša a podobní vědí, že antisemitismus je považován za špatný, a proto, aby mohli šíriti nenávist, musí používat krycí manévry, tj. levicovou, socialistickou či jinou ideologii.

Připomeňme, že Barša byl již v roce 2005 zařazen do výroční zprávy Fóra proti antisemitismu při Federaci židovských obcí v ČR. „Za jeden z nejzávažnějších trendů v loňském roce,“ konstatuje zpráva, „lze považovat kombinaci antisemitské, antisionistické, ale i antiamerické propagandy s fenoménem popírání či relativizování holocaustu. Šedesát let po osvobození Osvětimi je tak holocaust prezentován jako politický instrument, kterým židé, Izraelci a Američané vydírají svět a kterým ospravedlňují svou 'imperialistickou' mezinárodní politiku. Tento typ propagandy je šířen především organizacemi s totalitárními tendencemi (KSČM), některými intelektuály (P. Barša), ale i muslimskou komunitou. " ${ }^{33}$ Baršovo jméno, figurující ve zprávě spolu s rasistickými, antiromskými a skutečně antisemitskými organizacemi, tak symbolizovalo překročení hranice mezi „starým“ a „novým“ antisemitismem a s tím i nahrazení pojmu, u něhož bylo možné využít konkrétní společenskou a historickou relevanci, pojmem absorbujícím nevykořenitelnost, věčnost, a tedy analytickou neuchopitelnost protižidovského násilí. Komunistická strana Čech a Moravy představuje jednoduchý symbol totality, s nímž koncept „nového antisemitismu“ pracuje a který do sebe vtahuje široký rejstř́́k politicky „nenormálních“ názorů. Konečně odkaz na muslimskou komunitu nevyplývá ani tak z reálného zhodnocení situace, ale je spíše logickým doplňkem použití zmíněného výkladového schématu. ${ }^{64}$

Abychom pochopili výpovědi autorů ovlivněných výkladem dějin obětí, vraṫme se ještě na okamžik o krok zpět, k samotnému zrodu českého pojmu „nový antisemitismus“, jehož ekvivalenty prosazují v západním světě intelektuálové Pierre-André Taguieff (ve Francii), Josef Joffe (v Německu) či Alan Dershowitz a Christopher Caldwell (v USA) a další. Pojem u nás začal rezonovat spolu s otištěním článku „Globalizace antisemitismu“ od amerického historika Daniela J. Goldhagena v časopise Mezinárodní politika a postupně se dostává do širšího povědomí. Goldhagen píše o údivu nad spojením pravice a levice v otázce antisemitismu a o jeho znovuzrození vtěleném do kritiky Izraele. Závislost antisemitismu na sociálních nebo politicko-mocenských konfliktech se v Goldhagenově textu zdá být zcela volná, což víceméně odpovídá jeho nepolitickému, metafyzickému pojetí celého problému ${ }^{65}$

\section{Tamtéž.}

63 Výroční zpráva o antisemitismu v ČR 2005. Praha, Federace židovských obcí v ČR 2006, s. 13.

64 Jediná relevantní studie o tomto problému dokazuje naprostou okrajovost antisemitismu v české muslimské komunitě a palestinském hnutí (srv. TARANT, Zbyněk: „Nepřítel mého nepřítele...?“ Neonacismus a islám. Realita českého prostředí. In: BUDIL, I. - ARAVA-NOVOTNÁ, L. - TYDLITÁTOVÁ, V. - TARANT, Z.: Nová doba, stará zloba, s. 128-175 - viz pozn. 11).

65 Srv. GOLDHAGEN, Daniel J.: Globalizace antisemitismu. In: Mezinárodní politika, roč. 28, č. 10 (2004), s. 4 n. 
Právě toto pojetí se úspěšně prosazuje v diskurzu židovské národní identity. „Nový antisemitismus prokazatelně čerpá svou inspiraci ze všech dřívějších zdrojů - křestanských, islámských, levicových, pravicových a přidává $k$ nim i výtky antiglobalistické.“ Autor výroku Leo Pavlát zdánlivě paradoxně dodává, že „na počátku 21. století je zřejmé, že antisemitismus není ohlasem antisemitismu předválečného, ale že zaujaté protižidovské projevy mají současnou inspiraci. Spíše než o přežívající antisemitismus minulosti jde o antisemitismus obrácený k budoucnosti." Následující věta však explicitně vyjadřuje celkovou motivaci textu a narativní schéma „věčného antisemitismu“: „V tom tkví jeho největší nebezpečí. Protižidovská zášṫ s ním vstoupila do své nové éry." ${ }^{“ 6}$ Antisemitismus, jako neuchopitelný, nebot neustále se transformující (meta)historický jev, stojí prý v základech křestanské, islámské, pravicové i levicové kritiky a je nezávislý jak na chování samotného objektu kritiky (Izraele), tak na „dílčích“ ideologických východiskách kritiků. V tomto podání je fenomén antisemitismu v principu nezávislý na historickém čase, povznáší se nad něj, nebơ jej naplňuje eschatologií nenávisti a utrpení. ${ }^{67}$

Reakce na publikace Pavla Barši názorně ilustrují diskurz politiky identity, jak jej prosazuje část elity české židovské komunity. Viděli jsme, že dochází ke spojení nacionalistických východisek s konceptem totalitarismu ${ }^{68}$ Jedná se zde totiž o dva úzce související jevy: jednak o zmíněný výklad dějin a o politiku paměti založenou na etnocentrických prvcích, na „diskurzu původu“, jenž esencializuje určité kulturní znaky do podoby přirozené a historicky neměnné kolektivní identity; jednak o obranu národního Státu Izrael před jeho údajnými nepřáteli, ovládanými - jakoby víceméně samozřejmě - totalitními ideologiemi.

Zdá se, že svorníkem kolektivní identity českých, obvykle velmi sekulárně založených židů se spíše než ortodoxní či liberální judaismus - nebo než takzvaná česko-židovská asimilační identita, s př́iliš dlouho přerušenými tradicemi - může stát právě židovský nacionalismus. Může, ale nemusí zde přitom docházet ke konfliktu. V historii i současnosti (nejen židovského) nacionalistického hnutí prvky náboženské tradice národní identitu doplňovaly a rozšiřovaly schopnost nacionalistů integrovat cílovou populaci. ${ }^{69}$ Formování a reprodukci národní identity doprovází

66 PAVLÁT, Leo: Staronový antisemitismus. In: Tamtéž, s. 13 n.

67 Na jiném místě stejný autor prozrazuje svou náchylnost $\mathrm{k}$ mýtu vyvolení, stavícímu proti sobě židovskou toleranci a netolerantní svět, a dodává tomuto mýtu konkrétní tvar, jenž úzce souvisí s celým komplexem představ vyživovaných z dějin obětí: „Ano, židovská touha po porozumění, lásce a sounáležitosti je strhující. To ovšem Baršu a jeho mentory neopravňuje k tomu, aby ve světě, který takový, žel, není, vytvářeli konstrukt Židů nehumanistických, které osočují z ideologického zmocnění se paměti holokaustu v Izraeli a Spojených státech k podpoře údajného izraelského expanzionismu. "(TÝŽ: Židé, kteří vadí. In: Lidové noviny (17.7.2012), s. 3; také in: Roš chodeš, roč. 74, č. 8 (2012).)

68 K pokračující polemice srv. BARŠA, Pavel: Žid, který vadil. In: Lidové noviny (7.7.2012), s. 25; PAVLÁT, L.: Izrael na pranýŕi levice. V tomto článku Pavlát - na pozadí obdobné argumentace, kterou jsem zde analyzoval - srovnává Baršu s nacisty.

69 Blanka Soukupová konstatovala posilování partikulární židovské identity po roce 1989 na základě rozdělení dvou „modalit“ identity - „ortodoxněžidovské“ a „postholocaustově asimilantské“ (viz SOUKUPOVÁ, Blanka: Židovská menšina v České republice po rozpadu 
etnizace kulturních, náboženských a jiných symbolických prvků kolektivního života a sociálních vazeb komunity, kolem nichž a díky nimž je politický projekt národa postupně konstituován. Teprve pokud se tento proces zdaří, je cílová skupina politicky homogenizována a mobilizována $\mathrm{k}$ určitým národním cílům. ${ }^{70}$ Původně odlišné prvky kolektivních identit mohou být spojeny do relativně koherentního celku i - jak ukázala Esther Benbassová na př́kladě francouzských židů - pomocí „civilního náboženství “ založeného na paměti obětí. ${ }^{71}$

Židovští nacionalisté budují mezi evropskými židy a Izraelem samozřejmý a nezpochybnitelný vztah. „Židovský stát“ má jako symbolické jádro a politické centrum reprezentovat zájmy všech židů žijících v Evropě, Americe či jinde. Toto spojení je považováno za přirozené, nebot se prý zakládá na společném kulturním, či přímo genetickém původu a osudu všech židů, ohrožených protižidovskou nenávistí. ${ }^{72}$ Pevné pouto mezi Izraelem a českými židy (Židy) je testováno např́́klad na takzvaných preventivních vojenských útocích na sousední blízkovýchodní státy, na „boji proti terorismu" na Izraelem ovládaných palestinských územích a na dalších tématech. Značnou symbolickou hodnotu má např́klad odkaz na Mnichovskou dohodu, symbol „národní katastrofy“ $v$ roce 1938. S jeho vědomím Izrael je - či by měl být - podporován, aby se nemohla historická zkušenost českého národa opakovat v izraelských souvislostech a v situaci „globálního islámského terorismu“. ${ }^{33}$ Přenášení historické zkušenosti je ovšem oboustranné. Na pozadí budované loajality tak dochází k transferu blízkovýchodního konfliktu do českého prostředí. Na stránkách reprezentativního periodika Federace židovských obcí Roš chodeš se setkáváme s intenzivní agendou spadající do schématu dějin obětí; v časopise obecně dominují reference $\mathrm{k}$ minulému i současnému protižidovskému násilí. ${ }^{74}$ Klade se přitom

Československa: Život s židovstvím, češstvím a českoslovenstvím. O identitě českých Židů na základě vybraných veřejných minoritních projevi̊. In: ŠRAJEROVÁ, Olga (ed.): Migrace-tolerance-integrace, sv. 2. Opava, Slezský ústav Slezského zemského muzea - Informační kancelář Rady Evropy v Praze 2005, s. 169-182). Domnívám se ale, že je v současnosti nutné studovat i nacionalistickou identitu českých židů (Židů).

70 V daném př́ípadě ale nemusí jít o problém loajality vůči českému státu, spíše se nabízí možnost plurality loajalit.

71 BENBASSA, E.: Suffering as Identity, s. 139 nn. (viz pozn. 43).

72 Srv. např. KRAUS, Tomáš: Evropský židovský kongres v Praze. In: Roš chodeš, roč. 74, č. 6 (2012), s. 3. K argumentaci (genetickým) původem srv. RADIL, Tomáš: Židé, holokaust a Norman Finkelstein. In: FLEISCHMANNOVÁ, Jiřina - JELÍNEK, Tomáš - MACHAČOVÁ, Helena (ed.): Výzvy židovské současnosti 2010-2011: Kolektivní monografie. Praha, Spolek akademiků Židů 2011, s. 20-23. Tomáš Radil líčí národní identifikaci židů jako složitý, ale zároveň přirozený proces: „Diasporický charakter národní identity Židů, což je složitým a dynamicky se měnícím jevem, je založen na stupňující [se] vzájemné interakci a vzájemné podpoře obou složek, diaspory i domoviny. To je dlouhodobý geopolitický fenomén, s čímž musí Židé i jejich přátelé a nepřátelé počítat.“ (Tamtéž, s. 22.)

73 Srv. SIDON, Efraim K.: Novoroční dopis vrchního rabína. In: Roš chodeš, roč. 70, č. 10 (2008), s. 3; PETRÁČEK, Zbyněk: Kásámy z Gazy a sebeobrana. In: Tamtéž, roč. 71, č. 2 (2009), s. 3.

74 V daném př́padě má vypovídající, i když pouze druhotný význam kvantitativní analýza pojmů „holokaust“, „šoa“, „(židovská) genocida“, „antisemitismus“. Například v prvním 
důraz na spojení bezpečí komunity a mocenského postavení Izraele. ${ }^{75}$ Výpovědi o naléhavosti (ne)bezpečí bývají iniciovány př́ípady protižidovských útoků v Izraeli a jiných zemích, jejich obsah ale není jednosměrně utvářen těmito událostmi, nýbrž samotnou strukturou diskurzu, v němž hraje předporozumění událostem ve výše uvedeném řádu zásadní roli.

Zmíněná vazba mezi Izraelem a českou židovskou komunitou dovoluje nejen se solidarizovat s obětmi konfliktu, ale právě také posilovat pocity ohrožení. To lze doložit na diskusi týkající se Izraele, holokaustu a antisemitismu, ale také na proměně veřejných prostorů a architektuře. Ve veřejných budovách pražské židovské obce se objevují izraelské vlajky. Její domy komunitních sociálních služeb se budují jako fortifikační stavby svého druhu. Vůbec největší stavební projekt pražské obce Domov sociální péče - Hagibor - komentoval jeho architekt slovy, která dokládají rostoucí význam bezpečí v diskusích o židovském veřejném i soukromém životě: „Vnější zdi jsou ze železobetonu, okna jsou bezpečnostní a celý areál obklopuje plot, který vydrží náraz nákladního auta s trhavinou... “76 Přítomnost bezpečnostních zařízení a ochranky v podobných budovách se stala v minulých letech samozřejmostí. Na různých rovinách života české židovské komunity tedy vidíme propojení dvou souvisejících jevů: důrazu na pevnější, etnický charakter identity a tendence k fyzickému i symbolickému vymezení, doprovázenému diskurzem bezpečí. ${ }^{77}$ Členové obce mají být chráněni před nebezpečným světem; zkušenosti s protižidovskými útoky v samotné České republice jsou přitom minimální, byt̉ ani ty samozřejmě nelze zlehčovat. Jejich případné zesílení by kromě újmy způsobené jejich konkrétním obětem mohlo napomoci právě naznačenému procesu. ${ }^{78}$

Vývoj v posledních dvaceti letech, podmiňující obecné přijetí etnocentrické identity, se zdá pozvolný a patrně nelze mluvit jen o kontinuální „etnizaci“. Dříve než bude možné vyvodit přesnější závěry, je zapotřebí zevrubná analýza způsobů a míry

pololetí roku 2012 se v průměru v jednom čísle Roš chodeš vyskytovalo 35 těchto pojmů ve všech lexikálních podobách; přiřadit by se k nim ale musely i další termíny vztahující se k (protižidovskému) násilí (perzekuce, diskriminace, xenofobie, útisk, násilí aj.). Bude ale zapotřebí především pokračovat v analýze kvalitativní a ve výzkumu, nakolik si daný diskurz osvojili členové české židovské komunity.

75 Zaznívají tak např́klad varování, že konflikt s Íránem, který může následovat poté, co USA nevyjádří jednoznačnou podporu „židovskému státu“, bude znamenat přímé, fyzické ohrožení evropských židů, nebot posílí (již tak rostoucí) antisemitské nálady ve společnosti (srv. Evropský židovský kongres v Praze. In: Tamtéž, roč. 74, č. 6 (2012), s. 3).

76 Hagibor: Pevnost uvnitř Prahy. In: iDnes.cz [online]. 8. května 2008 [cit. 2016-11-18]. Dostupnéz: http://zpravy.idnes.cz/hagibor-pevnost-uvnitr-prahy-d2i-/domaci.aspx?c=A080505_130108_ praha_itu.

77 Zmíněný vývoj můžeme dokumentovat např́klad na Lauderových školách v Praze. Ty se dřive profilovaly jako školy s výukou hebrejštiny a židovské kultury, aby se postupně proměňovaly v instituci vyhrazenou dětem „židovských rodičů“, reprodukující „komunitu původu“. (Srv. MARXOVÁ, Alice: U Lauderů hlásí plné třídy: Několik otázek pro ředitelku LŠ Kateřinu Dejmalovou. In: Roš chodeš, roč. 74, č. 6 (2012), s. 11.)

78 To dokládá i Výroční zpráva o projevech antisemitismu v České republice za rok 2011 (Praha, Židovská obec Praha 2012). 
osvojování nacionalistických východisek a samozřejmě zkoumání podob rezistence vůči nim v různých částech dosud názorově pluralitní komunity. Přijetí národní identity je otázkou pokračujícího vyjednávání a sporů mezi odlišnými skupinami uvnitř českých židovských obcí. ${ }^{79}$ Je zapotřebí se tázat, jaké formy uznání mohou být pomocí nacionalismu artikulovány, jaké události a jevy byly a jsou pro formování židovské národní identity rozhodující atd. Je důležité analyzovat i to, jakou roli v tomto procesu hrála změna politického systému v roce 1989, a obecněji, jaké (dis)kontinuity ve vývoji etnické identifikace lze v poválečné komunitě československých židů zaznamenat. Jestliže existují první studie o reflexi židů a Izraele ze strany českých muslimů ${ }^{80}$ bude zapotřebí se na pozadí nastíněného jevu věnovat také reflexi muslimů (Arabů, Palestinců) ze strany židovské komunity. To vše jsou otázky, které s hlavním problémem tohoto textu souvisejí, ale je třeba na ně odpovědět pomocí orálněhistorických, sociologických a dalších analýz. ${ }^{81}$ Středobodem diskuse, na němž bude naznačený proces možné dále pozorovat, se zdá být antisemitismus a téma loajality vůči ,židovskému státu“. ${ }^{82}$

\section{Mezi politikou vědy a identity. Nepřátelé kultury, národa a demokracie}

Co v argumentaci některých nacionalistů může překvapovat, je používání liberálně-humanistického slovníku tolerance. Etnocentrický nacionalismus a určitý druh humanismu je však možné propojit. Tím se ovšem opět dostáváme k obecnějšímu jevu a oběma hlavním problémům, jimž se v této studii věnuji.

Baumanovu tezi o privatizaci holokaustu by bylo možné doplnit a vyostřit. „Privatizován" totiž nebyl pouze holokaust, ale do značné míry samotný fenomén antisemitismu. Holokaust, v pojetí zde analyzovaných dějin obětí, zastupuje článek řetězu nevykořenitelného zla, tisícileté nenávisti táhnoucí se z minulosti do budoucnosti. Jedinečnost události přitom nijak nekoliduje s její permanencí. Interpretace jsou

79 Rozpornost a hledání židovské identity vyjadřuje např. Martin Šmok v časopise liberální židovské veřejnosti Maskil. Uvádí zde mimo jiné: „Ve své většině tápeme ohledně židovské identity, jsme zmatení a stejně jako první poválečná generace nechápeme náhle pobožné konvertity, kteří se berou kdoví odkud. Nevíme, kde je naše místo a co jsme vlastně zač. Židovské tradice už nemůžeme nahradit ani vírou v Lenina, Stalina a komunismus, ani frázemi o zemi rozkvetlých kibuců, a většinou - alespoň snad my, co čteme Maskil - nechceme ani onu radikální asimilaci, po které tolik toužil prezident Beneš.“ (ŠMOK, Martin: Bílá místa. In: Maskil, roč. 6, č. 7 (2001-2002), s. 14 n.)

80 Srv. TARANT, Z.: „Nepř́itel mého nepřítele...?“ (viz pozn. 64).

81 Alena Heitlingerová ve své ojedinělé sociologické studii nabízí zajímavé poznámky o poválečné „symbolické komunitě etnického osudu“, o „civilním náboženstvi“", tj. podpoře Izraele po roce 1967, o „holokaustizaci“ polistopadové paměti českých židů atd. Otázkami vytčenými v této studii se ovšem zabývá minimálně. (Srv. HEITLINGEROVÁ, Alena: Ve stínu holocaustu a komunismu: Čeští a slovenští židé po roce 1945. Praha, G plus G 2007.)

82 Budování loajality k Izraeli nemusí znamenat zpochybnění úzkého vztahu k České republice; ke zvážení je i multiplicita loajalit a jejich uplatnění v různých politických a sociálních kontextech. 
naopak úzce provázány, holokaust je vyživován z historie věčného antisemitismu a naopak. Proto se holokaust zdá být logickým důsledkem a potvrzením historického vývoje (tisícileté nenávisti) i aktuální hrozbou současnosti (například v podobě „druhého holokaustu“ izraelských židů). Jedinečnost a permanence se v případě potřeby (ohrožení národa, mobilizace proti nepříteli) doplňují a vzájemně posilují. ${ }^{83}$

Problém, jak jsem nastínil výše, nepředstavuje jen pojetí židovských dějin jako dějin antisemitismu, ale rovněž interpretace pracující s dějinami antisemitismu jako s dějinami židů. Tyto roviny jsou úzce spjaty a vyplývají z propozic, jež spolu s Klausem Holzem nazývám korespondenční teorií. Nejhlubší důvod antisemitismu je přitom spatřován $v$ jinakosti vedle sebe existujících kultur (židovská versus křestanská, arabská, německá, česká atd.). Různorodost kulturních identit se ovšem prizmatem dnes ve vědě rozšířeného liberálního, humanistického multikulturalismu považuje za žádanou a nezbytnou k reprodukci demokratické společnosti. Jestliže dříve rasismus odstraňoval odlišné jako neidentické z těla společnosti, dnes střední proud multikulturalismu pokládá odlišnost kulturních identit za a priori dobrou a hodnou společenského uznání.

Étienne Balibar v knize Rasa, národ, tř́́da přesvědčivě ukázal, že ani obrat vědců a veřejnosti ke kultuře nemusí nutně znamenat kvalitativní změnu oproti dřívějšímu zahledění do biologických vlastností člověka a lidského druhu, na jehož základě docházelo k hierarchizaci a vylučování nepřizpůsobivého jako „přirozeně“, „od př́írody“ neidentického. Také „kulturně diferencialistický slovník“, jak daný postoj pojmenovává Balibar s odkazem na autory, jejichž guruem je Claude Lévi-Strauss, může naturalizovat sociální a politickou nerovnost. Kultura i př́roda za určitých okolností fungují stejně. Míšení je pak považováno za morálně odpudivý jev a kultura za něco, co spojuje individuum a skupinu s určitou genealogií, determinací vlastním původem. ${ }^{84}$ Pomocí kultury lze homogenizovat určitý sociální prostor, a naopak jádro sociálních konfliktů může být spatřováno v odlišnosti kulturních identit. Z tohoto úhlu pohledu se zdá, že samotná politika vychází z jakéhosi kulturněidentitního jádra. Tím je ovšem politika jako střet odlišných skupinových zájmů a hodnot závislých na čase a prostoru fakticky nahrazena osudem, přesněji stř̌etem esenciálních a lidským jednáním nezměnitelných jinakostí.

Na základě kulturalistického, potažmo devalvovaného (kvazi)multikulturního paradigmatu, jež nemá s autentickým multikulturním projektem ve skutečnosti mnoho společného, je možné hierarchizovat jednotlivé kultury podle toho, jestli patř́ ke kultuře univerzalistické a progresivní, anebo partikulární a primitivní (barbarské). Kulturní diferencialismus touto cestou aplikuje staré normy na nové situace. Novou funkci získávají metaforické dichotomie „otevřené versus uzavřené“, „rozvíjející se versus statické“, „chladné versus horké“. (Například kvality starého, „orientálního

83 Srv. ZERTAL, I.: Israel's Holocaust, s. 91-127 (viz pozn. 48). „Lokální konflikt získává díky paměti holokaustu nový význam, je jím extrahován z konkrétního politického a historického kontextu, zatímco diskurz konfliktu naopak konsoliduje a podpírá roli holokaustu jako stěžejního mýtu sionisticko-izraelského metanarativu." (Viz tamtéž, s. 167.)

84 BALIBAR, Étienne - WALLERSTEIN, Immanuel: Race, Nation, Class: Ambiguous Identities. London, Verso 1991, s. 22 n. 
Východu“ dědí arabské, západnímu způsobu života údajně nep̌rizpůsobivé obyvatelstvo, zatímco civilizace zůstává na straně „bílého Západu“.) Abychom nevynechali centrální bod liberálního, respektive neoliberálního myšlení, je ale nutné dodat, že základním symbolickým, strukturujícím prvkem kapitalistické společnosti je individualismus. Kultura umožňující rozvoj individualismu a volnotržních vztahů je tedy postavena na vrchol pyramidy. ${ }^{85} \mathrm{~V}$ jistém smyslu to může „oblast civilizace" rozšíritit, ${ }^{86}$ hierarchie tím nicméně neztrácí na účinnosti. Současná podoba hegemonie se reprodukuje pomocí politického jazyka, jehož centrum leží právě na průsečíku individualismu a kulturního diferencialismu.

Objevuje se řada otázek a pochybností. Zaprvé se z diskuse vytrácí otázka, zdali jsou hodnoty „vždy dobré“ kultury zobecnitelné, tedy jestli v určitém čase a kontextu daná kultura vytváří prostředí pro uplatnění norem politické a sociální rovnosti. O jak problematický postoj se může jednat, vidíme na kulturalistické rétorice současného pravicově radikálního a neonacistického hnutí. Odehrává se na propustné hranici kulturalismu, jehož potenciál je využíván i těmi, kteří se zaštitují mnohostí a tradičními hodnotami kultur, aby dodávali, že jejich míšení vždy podněcuje společensky nežádoucí jevy: degeneraci, úpadek civilizace a podobně. Kulturní jinakost se stala důležitou součástí jazyka nacionalismu i imperialismu (neokolonialismu) a autentické liberální myšlení se s touto ztrátou jen neobratně vyrovnává.

Abych zůstal věrný vlastní terminologii, nazvu daný př́stup, jak je aplikován v historické vědě, metodologickým kulturalismem. Obvykle se dnes v historiografii a obecně v humanitních a sociálních vědách nesetkáváme s rasou a krví coby znaky kolektivní př́slušnosti. Tím, s čím se naopak střetáváme poměrně často, je symbolické „uzavřeni““ aktérů v židovské, české, islámské a jiné kultuře. Na některých historických, ale také antropologických, sociologických i jiných textech lze ukázat, jak kultura mechanisticky nahradila pojmy národa a rasy, aniž by vědci do důsledku revidovali předpoklady rasismu a nacionalismu. Přistoupíme-li k problému konkrétněji, poměrně intenzivně se kulturalismus ozývá např́íklad v chápání dějin takzvané rudé asimilace. ${ }^{87} \mathrm{~V}$ české akademické obci i veřejné diskusi se ovšem začíná dostávat ke slovu především díky „novému antisemitismu“, a to zvláště tam, kde dochází

85 Tamtéž, s. 25.

86 V tomto smyslu by bylo zajímavé srovnat diskuse o Izraeli a o Číně a jejím postupném, i když nikoliv nekonfliktním přijetí mezi „civilizované národy“, jak dosud probíhají na pozadí ekonomické transformace.

87 V českém prostředí se téma příklonu židů k radikální levici rozvinulo jen okrajově. Za ukázkové texty co do prýstupu hledajícího za levicovou identifikací židů jakousi „židovskou esenci“ lze označit práce Ernsta Nolteho či Alexandra Solženicyna (srv. NOLTE, Ernst: Streitpunkte: Heutige und künftige Kontroversen um den Nationalsozialismus. Berlin, Propyläen 1994, zvl. s. 323-334; SOLŽENICYN, Alexander: Dvě stě let pospolu: Dějiny rusko-židovských vztahů v letech 1795-1916. Praha, Academia 2004.) Zařazení Solženicynovy knížky na stránky rasistického Národně vzdělávacího institutu je logické (dostupné online z: http://www.vzdelavaci-institut.info/?q=node/534 [cit. 2016-12-16]). Výmluvný je i zájem o knihu na jednom z nejznámějších českých xenofobních webových fanzinů Zvědavec (viz STWORA, Vladimír: Komu a čemu slouží autorský zákon: Jak jsem se pokoušel „hrát podle pravidel“. In: Zvědavec [online]. 14. února 2012 [cit. 2016-12-16]. Dostupné 
k identifikaci takzvané islámské hrozby. Vzhledem $\mathrm{k}$ jeho potenciálu si dovolím předpovědět, že se s ním budeme stále častěji setkávat $v$ souvislosti s hodnocením soudobých dějin, například dějin sociálních hnutí a vývoje multikulturního soužití v evropských zemích, Spojených státech, Izraeli i jinde.

Walter Laqueur, Christopher Caldwell, Emanuele Ottolenghi, Clemens Heni a jiní autoři mají díky překladům svých knih, článkům či rozhovorům vliv na zobecnění „nového antisemitismu“ v českém prostředí. ${ }^{88}$ Mezi jmenovanými autory jsou názorové rozdíly, spojuje je nicméně představa o přirozenosti a esenciální odlišnosti kultur a často též přesvědčení o možném, či již aktuálně probíhajícím střetu západní a muslimské kultury. Panuje mezi nimi implicitní či explicitní odpor $\mathrm{k}$ „míšení kultur“, údajně ohrožujícímu západní civilizaci. ${ }^{89}$ Kauzou, na níž se podle nich dá

z: http://www.zvedavec.org/komentare/2012/02/4822-komu-a-cemu-slouzi-autorsky-zakon.htm).

88 Islamofobie není vlastní všem autorům přejímajícím koncept „nového antisemitismu“. Nabízí ovšem perspektivu pro všechny zklamané z (domnělého či faktického) neúspěchu multikulturalismu, kterou mohou využít ke svým výpadům proti „míšení kultur“.

89 Caldwell se vrací ke starým argumentům biologického ohrožení. Tento autor literatury nazývané green peril představuje spojnici neokonzervativismu, islamofobie, kulturalismu a „věčného antisemitismu“. Ke kritice jeho vlivné knihy Reflections on the Revolution in Europe: Immigration, Islam, and the West (New York, Doubleday 2009) srv. recenzi Mata Carra (CARR, Matt: Christopher Caldwell dissected. In: Institute of Race Relations [online]. July 2, 2009 [cit. 2016-11-01]. Dostupné z: http://www.irr.org.uk/news/christopher-caldwell-dissected/). Nezdá se být žel náhodou, že Caldwell dostal prostor v Roš chodeš, a to jako odborník na „muslimskou otázku“ a antisemitismus (srv. CALDWELL, Christopher: Antisemitismus a antisionismus. In: Roš chodeš, roč. 74, č. 1 (2012), s. 16 n.). Viz také LAQUEUR, W.: Měnící se tvář antisemitismu (viz pozn. 54). „Biologické ohroženi““ Evropy ze strany „sexuálně deprivovaných“ Arabů představuje Laqueur v knize Poslední dny Evropy: Humanistická Evropa, nebo islamistická Eurábie? (Praha, Nakladatelství Lidové noviny 2006, zvl. s. 40 n.). Podle Ottolenghiho je správná židovská identita bud' náboženská, nebo nacionalistická, zato asimilace je aktem „sebenenávisti“: „Antisemitské předsudky se skrývají za antisionismus, a Žid, který se k chóru protiizraelských obvinění připojuje, mu nevyhnutelně poskytuje alibi. (...) Pro Žida, který toto alibi nabídne a který nenávidí své bratry, je odsouzení Izraele aktem autodafé. Jeho autodafé spočívá v tom, že obvinil Izrael, že svou existencí a konáním zradil ducha a literu prorocké tradice, čímž se sám snaží vymanit $\mathrm{z}$ nepohodlné identity, které dává přednost většina Židů v diaspoře a v Izraeli." (OTTOLENGHI, E.: Autodafé Evropa, s. 218 - viz pozn. 54.) Ukázku „nového antisemitismu“ smíchaného s islamofobií poskytuje např. článek: HENI, Clemens: Shoah Remembrance and new anti-Semitism: Derealization, Universalization, and Trivialization of the Holocaust and anti-Semitism. In: TYDLITÁTOVÁ, V. - HANZOVÁ, A. (ed.): Reflection on Anti-Semitism, s. 26-34 (viz pozn. 11). Koncept „nového antisemitismu“ přejímají v dané podobě i někteří badatelé věnující se současnému levicovému či akademickému antisemitismu (viz např. TYDLITÁTOVÁ, V.: Akademický antisemitismus - viz pozn. 57). K typickému spojení argumentace „věčného/nového antisemitismu“, nacionalismu a kulturalismu v českém prostředí velmi ilustrativně viz PAVLÁT, Leo: Persekuce Židů jako historický fakt. In: VEBER, Václav a kol.: Židé v novodobých dějinách. Praha, Karolinum 1997, s. 125-146. Je př́íznačné, že v rámci nacionalistického diskurzu, který se v citovaném textu plně uplatňuje, jsou odlišné varianty (nenárodní) identifikace posuzovány jako něco nepřirozeného. $\mathrm{V}$ takto podávaných dějinách se obvykle 
dobře ukázat onen fundamentální konflikt kultur, vyjevující se s obzvláštní silou v podobě úpadku morálky a tradičních hodnot Západu, je údajně právě „nový antisemitismus". Islámskou evropskou komunitu tito autoři obvykle charakterizují apriorní netolerancí a protižidovskou nenávistí, sublimovanou v kritice Izraele. „Nekompatibilni“" kultura navíc v jejich očích našla podporu v nové radikální levici, v akademických liberálech a - jak někteří dodávají - v židech stižených sebenenávistí. ${ }^{90}$ Normální žid je podle nich ten, jenž prožívá svou identitu etnicky, národně a logicky pak vyjadřuje loajalitu „ke svému“ národnímu státu. Tyto argumentace dokumentují, o jak normativní tvrzení se koncept „nového antisemitismu“ opírá a jak koncentrovaně esenciální obsah se skrývá pod definicí kultury a identity jeho obhájců.

Kulturalismus se v jazyce některých vědců a židovské etnocentrické politiky identity propojuje s nacionalistickým a totalitárním diskurzem. Islámská hrozba, sebenenávidějící se (asimilovaný apod.) žid a antisemitská, totalitářská levice představují ohrožení morálky, tradice, svobody, kultury. Židovský národ, Izrael a západní kultura vystupují naopak v roli oběti, která se musí bránit, aby uhájila demokratický ráa. Nakolik je v daný moment skutečně obrana obranou a demokracie demokracií, většinou poznáme podle toho, v jaké míře jsou zastoupeny výše zmíněné argumenty a obestřeny vypjatě moralizujícími kategoriemi. ${ }^{91}$

\section{Závèr}

Inspirován prací Klause Holze jsem ve své studii stanovil základní strukturu heterogenního pole psaní o dějinách českých židů. Výkladový rámec („korespondenční model"), který poměrně mnoho českých badatelů a badatelek v daném období (1989-2012) volilo, předznamenává zavádějící chápání antisemitismu jako jevu, který reaguje na sociální, politické, ekonomické a jiné „zvláštní postavení“ židů a přinejmenším implicitně postuluje apriorní jinakost, ne-identitu a v extrémním př́padě dokonce nekoherenci židovských a českých (německých apod.) dějin. Židé, respektive židovský národ mají podle takového výkladu nesouměřitelně ,jiné dějiny“, zaplněné výhradně nebo téměř výhradně tragickými milníky pronásledování; antisemitismus je přitom zdánlivě „logickou“ reakcí na (esenciální) jinakost židů;

setkáváme s tvrzením o „sebenenávisti asimilantơ“; asimilace je vydávána za morálně odpudivý jev, v akademičtější rétorice se objevují formulace např. o „sebenegativním vnímáni“" (viz tamtéž, s. 137). Úzká příbuznost východisek Ottolenghiho a Pavláta je zjevná např. v Pavlátově článku „Izrael na pranýrí levice“ v Lidových novinách (viz pozn. 56). Kriticky k delegitimizaci židovských kritiků Izraele jako „sebenenávidějících se židư“ viz FINLAY, W. M. L.: Pathologizing Dissent: Identity Politics, Zionism and the "Self-Hating Jew". In: British Journal of Social Psychology, roč. 44, č. 2 (2005), s. 201-222.

90 Ke kritice tohoto pojmu a jeho roli v politice židovské identity srv. FINLAY, W. M. L.: Pathologizing Dissent, s. 209 nn.

91 Dále k tématu viz BARTÁKOVÁ, Daniela - STROBACH, Vít: Válka, sex a Orient očima „nových Židů“. In: Biograf, č. 57-58 (2012-2013), s. 55-75. 
„logickým“ vyústěním takto zacyklených dějin násilí je holokaust a vznik Státu Izrael jako bezpečného ostrova $v$ nepřátelském světě.

Studie se zaměřila na detailnější rozčlenění „dějin obětí", na typické formy výkladu o dějinách židů, respektive antisemitismu, které zapadají do tohoto schématu. Výsledkem je rozlišení tří paradigmatických výpovědí české historiografie: metodologického nacionalismu, metodologického totalitarismu a metodologického kulturalismu. Vylícil jsem, v jakých konstelacích se s nimi setkáváme ve vědě, ale i ve veřejné diskusi, která ovlivňuje politiku identity českých židů.

Dějiny židů zaklíněné ve výkladu o věčném antisemitismu a jeho obětech jsou ilustrativním př́kladem historie-paměti operující v prostoru vědy-politiky a konstruující v mnoha ohledech problematickou, negativně se vymezující kolektivní identitu. Identitu, která je na mnoha rovinách formována esenciálním, deterministickým pojetím národa a kultury a diskurzem bezpečí, jenž rozlišuje přátele a nepřátele podle esenciálních kvalit a kategorií spíše než podle politických názorů a konkrétního sociálního a kulturního kontextu mezilidských vztahů.

Výzkum byl podpořen grantem Grantové agentury ČR č. GPP410/12/P671 „Politiky židovské identity $v$ českých zemích (1860-1938)“. 